\title{
Experimental Study and Effective Width Method for Cold-Formed Steel Lipped Channel Stud Columns with Holes
}

\author{
Yanli Guo $\mathbb{D}^{1}$ and Xingyou Yao $\mathbb{D}^{2}$ \\ ${ }^{1}$ School of Civil Engineering and Architecture, Nanchang University, Nanchang, China \\ ${ }^{2}$ Jiangxi Province Key Laboratory of Hydraulic and Civil Engineering Infrastructure Security, Nanchang Institute of Technology, \\ Nanchang, China \\ Correspondence should be addressed to Yanli Guo; 2013994413@nit.edu.cn
}

Received 5 March 2021; Revised 13 May 2021; Accepted 10 June 2021; Published 23 June 2021

Academic Editor: Adolfo Preciado

Copyright (c) 2021 Yanli Guo and Xingyou Yao. This is an open access article distributed under the Creative Commons Attribution License, which permits unrestricted use, distribution, and reproduction in any medium, provided the original work is properly cited.

\begin{abstract}
The objective of this paper is to investigate the buckling behavior and to present the design method of the ultimate strength in the basic effective width method (EWM) for cold-formed steel (CFS) lipped channel stud columns with holes in the web. 28 column tests were conducted under axial compression on the CFS lipped channel stud columns with circular and rectangular holes in different dimensions of cross sections and holes. The tested stud columns included 4 members without holes, 12 members with circular holes, and 12 members with rectangular holes. The test results showed that the stud columns with holes were governed by local buckling or the interaction of local buckling and distortional buckling. Compared with the stud columns without holes, the small hole had a slight influence on the ultimate strength of the tested specimens, and the large hole had a great effect on the ultimate strength of the tested specimens. The load capacities of the specimens decreased with the increase of the dimension of holes. Then, the finite element analysis was carried out to simulate the tested stud columns. The finite element analysis results showed good agreement with the experimental results about buckling modes and ultimate strengths, which indicated that it is feasible to analyze this kind of stud columns with holes by using the finite element method (FEM). Finally, the proposed effective width method was used to predict the ultimate strengths of stud columns with holes based on the proposed buckling coefficient formulas of the plate with holes. The comparison between calculated results and test and finite element results indicated that the proposed EWM is feasible and accurate to predict the ultimate strength of the CFS lipped channel stud columns with holes in the web.
\end{abstract}

\section{Introduction}

The cold-formed steel commercial and residential buildings have become increasingly popular during the past few decades because CFS has high strength and stiffness, convenient manufacturing and transportation, and a high construction speed. The lipped channel section is commonly used in the studs and beams for CFS constructions. However, the holes often can be seen at the web of CFS lipped channel sectional columns or beams because of the installing of the electrical, heating, and other conduits. The presence of holes in the CFS members can lead to the decreasing of the cross-sectional area and stiffness. Therefore, the influence of the hole on the buckling behavior and design method of ultimate strength of CFS lipped channel members should be studied.

Some works have been conducted by researchers to study the effect of holes on the buckling behavior and load capacity of CFS lipped channel columns. Stub column tests indicated that the ultimate load capacities would decrease with the increase of the diameter of circular holes [1]. The same conclusions have been reported for the tested CFS columns with circular, rectangular, and slotted web holes $[2,3]$. The compression tests of short and intermediate length CFS lipped channel columns with slotted web holes conducted by Moen and Schafer [4] showed that the 
presence of holes led to a slight decreasing in the ultimate strength and the changing of buckling modes. The tested CFS C-shape columns with slotted holes displayed distortional buckling [5]. The experimental results indicated that holes resulted in a decrease in the load capacities slightly, and the modified direct strength method was presented to predict the ultimate strength. The intermediate columns with circular holes conducted by $\mathrm{He}$ and Zhao [6] showed that the stresses of the plates adjacent to the holes were higher than those of other parts and yielded early than other parts. The C-shaped section slender columns with web openings tests indicated that all slender compression specimens displayed the flexural-torsional buckling, and the ultimate strengths of the specimen were slightly reduced because of the web opening [7]. The lipped channel columns with web stiffener and holes were studied by Yao et al. [8], and the numerical and experimental results illustrated that the presence of holes changed the bucking modes of columns and decreased the ultimate strengths.

In order to develop the new direct strength method to determine the ultimate strength of perforated columns, the calculated method of the elastic buckling load or stress and direct strength method have been studied by some researchers. The simplified methods to predict the critical elastic global, distortional, and local buckling loads of CFS columns with holes were developed based on theoretical and numerical analysis [9]. In the basic finite element analysis, the new design formulas for predicting the elastic distortional buckling stress of perforated columns were presented [10]. Based on theoretical and experimental studies, the modified direct strength methods were proposed to predict the ultimate strength of perforated columns [11].

Currently, the ultimate strength of CFS members can be determined using the effective width method and the direct strength method in some specifications $[12,13]$. However, the effective width method is the only design method to predict the ultimate strength of CFS members with holes. Meanwhile, the design provisions in AISI 2016 and Chinese code GB50018 are only suitable for the columns with holes whose maximum dimension is less than the half-height of the web. The ultimate strength of CFS members with large holes cannot be obtained using these codes.

Despite a few existing works, a lack of understanding of buckling behavior of the stud columns with large holes in the web under axial compression and absence of the design method often led to the design by using overconservative assumptions which prevent the use of the lipped channel section with holes. Thus, this paper aims to provide detailed research on the CFS lipped channel stud columns with circular and rectangular holes in the web. Furthermore, the finite element model (FEM) was validated by using test results. The proven FEM was used to analyze the effect of the dimension of hole on the ultimate strengths of the CFS lipped channel stud columns with holes. Finally, the new effective width design method was proposed to predict the ultimate strength of CFS lipped channel stud columns with holes based on test and finite element analysis (FEA) results.

\section{Design of Experiments}

2.1. Specimens' Geometry. To study the effect of local buckling and interaction buckling behavior, 28 CFS lipped channel stud columns with a nominal thickness of $0.8 \mathrm{~mm}$ and $1.0 \mathrm{~mm}$ under axial compression were selected to test, including 4 stud columns without holes, 12 stud columns with circular holes, and 12 stud columns with rectangular holes. These sections had a large width-to-thickness ratio and would fail in local buckling under loading. Section 9008 is the engineering section used in China, and section 10010 is the designed section that can fail with interaction with local buckling and distortional buckling. There was only one hole at the web of the midheight of stud column for all specimens. The definitions of geometric parameters of stud column and types of holes are depicted in Figure $1, h, b, a, t$, and $L$ are the height of the web, the width of the flange, the height of the lip, the thickness of the section, and the length of the specimen, respectively. The diameters of circular holes $(d)$ were $0.3,0.5$, and 0.7 to the height of the web in order to consider the effect of different sizes of holes. The nominal dimensions of the specimen and holes are listed in Table 1. In order to reduce the number of specimens, the ratio of length to width of the rectangular hole $\left(L_{h} / H_{h}\right)$ for all specimens with rectangular holes was equal to 2 . The specimens were labeled as shown in Figure 2. For example, the label "C900803-CH3-1" defines the specimen as follows: $\mathrm{C}$ indicates that the section is a lip channel section stud column; 9008 means that the nominal height of the web and the nominal thickness of the section are $90 \mathrm{~mm}$ and $0.8 \mathrm{~mm}$, respectively; $\mathrm{CH} 3$ represents that the section has a circular hole and the ratio of the diameter of the circular hole to the height of the web is 0.3 ; 1 represents the sequence number of the same specimens. The cross-section dimensions of all specimens are measured and tabulated in Table 2.

2.2. Initial Geometric Imperfection Measurements. Initial imperfections resulting from forming and transportation have a great influence on the buckling behavior of CFS members. So, the initial imperfections of all specimens along the longitudinal direction were measured before the test. The interval of longitudinal location measured was $30 \mathrm{~mm}$. The measuring locations of cross section are illustrated in Figure 3, including the initial local imperfection, the initial distortional imperfection, and the initial global imperfection about the weak axis and great axis of lipped channel section for locations 1, 2, 3, and 4, respectively. The initial imperfections of specimen C9008-03CH3-1 are depicted in Figure 4. The initial imperfection distributions of the other specimens were the same as specimen C9008-03-CH3-1. The initial imperfections indicated that the imperfections of the CFS lipped channel stud columns had no obvious laws along the longitudinal direction. But we need to note that the value of the local imperfection is larger than the distortional and overall imperfection for stud columns. The maximum initial geometric imperfection magnitudes $\left(\Delta_{\max }\right)$ for all specimens are listed in Table 2. 


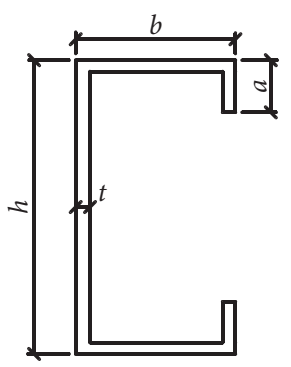

(a)

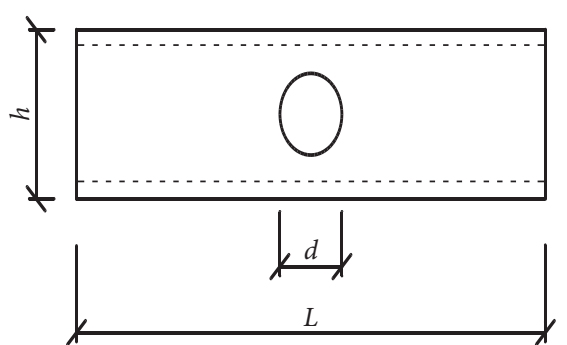

(b)

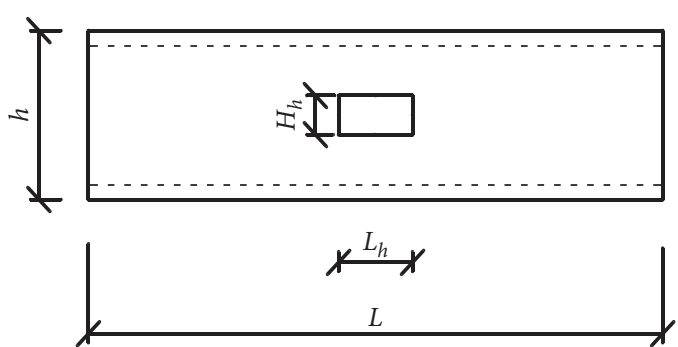

(c)

Figure 1: Section definition and hole sizes for CFS stud columns. (a) Lipped channel section. (b) Circular hole. (c) Rectangular hole.

TABle 1: Nominal dimensions of tested stud columns.

\begin{tabular}{lccccccc}
\hline Specimen & $L(\mathrm{~mm})$ & $h(\mathrm{~mm})$ & $b(\mathrm{~mm})$ & $a(\mathrm{~mm})$ & $t(\mathrm{~mm})$ & $d / h$ & $H_{h} / h$ \\
\hline C9008 & 300 & 90 & 50 & 15 & 0.8 & $0.3,0.5,0.7$ & $0.2,0.4,0.6$ \\
C10010 & 500 & 100 & 90 & 10 & 1.0 & $0.3,0.5,0.7$ & $0.2,0.4,0.6$ \\
\hline
\end{tabular}

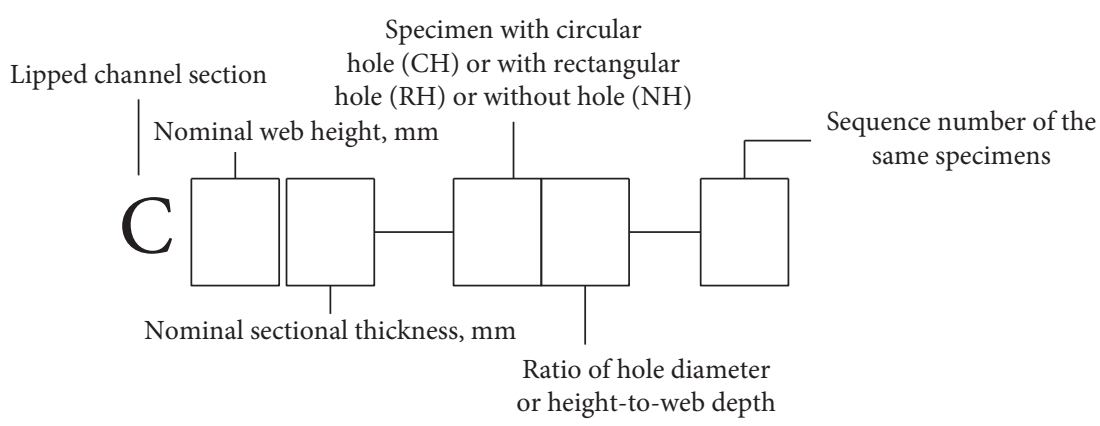

FIGURE 2: Stud column naming convention.

2.3. Test Setup and Instrumentation. The reaction frame system and a $500 \mathrm{kN}$ hydraulic Jack were used to apply axial compression load on all specimens at a speed of $0.02 \mathrm{~mm} / \mathrm{s}$ as shown in Figure 5. The upper actuator and lower pedestal were fitted with $250 \mathrm{~mm} \times 200 \mathrm{~mm} \times 8 \mathrm{~mm}$ thick steel platen ground flat and parallel. The column specimens were put directly on the steel platen as they were compressed. Friction between the column ends and the steel platens were the only lateral forces that restrained the column cross section under load. A load cell measured the applied compression force on each specimen. The displacement transducers and strain gauges were adopted to capture the displacement, deformation, and stress of the specimen during the loading process as illustrated in Figure 6. For specimens without holes, four position transducers (Figure 6(a)) were used to record the lateral deformations, and four strain gauges (Figure 6(b)) were arranged to measure the stress of the web. This instrumentation is set at the midheight of the stud column. At the midheight of all specimens with holes, four position transducers (Figure 6(c)) and four strain gauges (Figure 6(d)) were positioned. At the web at about $50 \mathrm{~mm}$ higher than the midheight of specimens with holes, three position transducers and four strain gauges were employed as depicted in
Figures 6(e) and 6(f). A position transducer was set at the upper endplate of the specimens to measure the vertical displacement under axial load for all specimens.

2.4. Material Properties. A series of coupon tests were completed to determine the basic material properties of the stud columns. The coupons were cut along the longitudinal direction of specimens. 3 tensile coupons were tested based on Chinese specifications GB/T228.1-2010 [14] for each kind of thicknesses of the steel sheets. The measured average material properties of initial Young's modulus $(E)$, the $0.2 \%$ proof stress $\left(f_{0.2}\right)$, the tensile strength $\left(f_{u}\right)$, and the ultimate strain $\left(\varepsilon_{u}\right)$ are summarized in Table 3.

\section{Test Results}

3.1. Buckling and Failure Modes. Table 4 presents the test results of 28 CFS stud columns with holes under axial compression including the buckling modes and load capacities, where $L$ and $D$ represent the local buckling and distortional buckling, respectively. Two kinds of buckling modes were observed for all tested specimens, local buckling and interaction buckling of local and distortional buckling. 
TABLE 2: Measured dimensions of tested stud columns.

\begin{tabular}{|c|c|c|c|c|c|c|c|c|c|c|}
\hline Specimen & $h_{1}(\mathrm{~mm})$ & $b_{1}(\mathrm{~mm})$ & $b_{2}(\mathrm{~mm})$ & $a_{1}(\mathrm{~mm})$ & $a_{2}(\mathrm{~mm})$ & $L_{1}(\mathrm{~mm})$ & $d_{1}(\mathrm{~mm})$ & $H_{h 1}(\mathrm{~mm})$ & $L_{h 1}(\mathrm{~mm})$ & $\Delta_{\max }(\mathrm{mm})$ \\
\hline C9008-03-NH-1 & 87.68 & 49.06 & 49.29 & 15.06 & 15.19 & 299.50 & - & - & - & 0.54 \\
\hline C9008-03-NH-2 & 88.35 & 49.27 & 49.41 & 14.59 & 14.79 & 299.48 & - & - & - & 0.48 \\
\hline C9008-03-CH3-1 & 89.69 & 48.96 & 49.53 & 14.61 & 14.74 & 299.67 & 27.03 & - & - & 0.60 \\
\hline C9008-03-CH3-2 & 86.97 & 49.31 & 49.64 & 14.49 & 15.19 & 299.71 & 27.01 & - & - & 0.44 \\
\hline C9008-03-CH5-1 & 87.41 & 49.67 & 49.98 & 15.67 & 15.07 & 299.50 & 45.11 & - & - & 0.48 \\
\hline С9008-03-СH5-2 & 87.50 & 48.98 & 49.04 & 15.16 & 15.00 & 299.69 & 45.04 & - & - & 0.46 \\
\hline C9008-03-CH7-1 & 88.98 & 49.92 & 48.92 & 15.42 & 14.64 & 299.67 & 62.87 & - & - & 0.39 \\
\hline C9008-03-CH7-2 & 86.35 & 49.36 & 49.14 & 14.84 & 14.60 & 299.65 & 63.06 & - & - & 0.67 \\
\hline C9008-03-RH2-1 & 88.25 & 49.19 & 50.38 & 14.62 & 14.49 & 299.60 & - & 18.12 & 36.15 & 0.32 \\
\hline C9008-03-RH2-2 & 88.30 & 49.12 & 49.62 & 14.46 & 14.73 & 299.80 & - & 18.10 & 36.12 & 0.30 \\
\hline C9008-03-RH4-1 & 89.22 & 48.89 & 49.28 & 14.47 & 14.42 & 299.10 & - & 36.11 & 72.14 & 0.35 \\
\hline C9008-03-RH4-2 & 88.54 & 49.62 & 48.90 & 14.84 & 14.32 & 300.10 & - & 36.16 & 72.12 & 0.37 \\
\hline C9008-03-RH6-1 & 88.85 & 48.84 & 49.04 & 15.26 & 14.91 & 299.90 & - & 54.14 & 108.22 & 0.45 \\
\hline C9008-03-RH6-2 & 88.73 & 48.69 & 49.22 & 14.80 & 14.64 & 299.89 & - & 54.17 & 108.08 & 0.49 \\
\hline C10010-05-NH-1 & 99.25 & 90.05 & 89.19 & 9.04 & 8.83 & 482.77 & - & - & - & 0.47 \\
\hline C10010-05-NH-2 & 97.97 & 89.13 & 89.14 & 9.56 & 9.98 & 495.74 & - & - & - & 0.49 \\
\hline C10010-05-CH3-1 & 95.76 & 90.01 & 89.71 & 10.23 & 9.54 & 499.63 & 29.90 & - & - & 0.45 \\
\hline C10010-05-CH3-2 & 96.03 & 89.81 & 89.53 & 9.73 & 9.68 & 499.86 & 29.88 & - & - & 0.51 \\
\hline C10010-05-CH5-1 & 95.71 & 89.60 & 89.95 & 9.75 & 10.10 & 499.77 & 50.01 & - & - & 0.55 \\
\hline C10010-05-CH5-2 & 96.60 & 89.80 & 90.39 & 9.10 & 9.44 & 499.74 & 49.94 & - & - & 0.50 \\
\hline C10010-05-CH7-1 & 97.79 & 89.96 & 89.87 & 9.24 & 9.44 & 499.83 & 70.06 & - & - & 0.6 \\
\hline C10010-05-CH7-2 & 95.44 & 89.45 & 89.73 & 9.82 & 9.94 & 499.21 & 69.98 & - & - & 0.47 \\
\hline C10010-05-RH2-1 & 97.70 & 90.04 & 89.27 & 9.65 & 9.23 & 499.43 & - & 20.10 & 39.96 & 0.28 \\
\hline C10010-05-RH2-2 & 99.27 & 89.62 & 89.61 & 9.58 & 9.16 & 499.58 & - & 20.06 & 39.95 & 0.37 \\
\hline C10010-05-RH4-1 & 99.37 & 89.58 & 90.02 & 9.32 & 9.24 & 499.50 & - & 39.95 & 80.07 & 0.33 \\
\hline C10010-05-RH4-2 & 98.18 & 89.23 & 88.71 & 9.78 & 9.43 & 499.97 & - & 40.07 & 79.96 & 0.49 \\
\hline C10010-05-RH6-1 & 96.75 & 89.80 & 89.81 & 9.34 & 9.39 & 499.41 & - & 60.17 & 120.00 & 0.55 \\
\hline C10010-05-RH6-2 & 98.21 & 89.44 & 88.78 & 9.64 & 9.49 & 499.84 & - & 60.17 & 120.04 & 0.62 \\
\hline
\end{tabular}

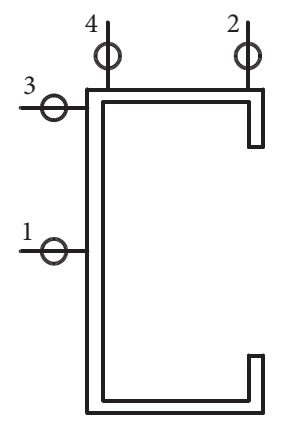

Figure 3: Measure location of initial imperfections.

3.1.1. Section C9008 Series. The buckling progress of specimens for section C9008 series is depicted in Figure 7 (specimen C9008-03-CH3-1) and Figure 8 (specimen C9008-03-RH6-1). The specimens with small holes failed in the interaction of local buckling and yield of cross section, whereas the specimens with large holes displayed the interaction of local buckling and distortional buckling. As shown in Figure 9, specimen C9008-03-CH3-1 displayed local buckling in the web (Figure 9(a)) firstly, and local buckling in the flange (Figure $9(\mathrm{~b})$ ) occurred gradually with the increase of loading. Then, local buckling in the lip (Figure 9(c)) was observed. Finally, the specimen failed with the plastic crush at the location of the large buckling deformation as shown in Figure 9(d). The other specimens with small holes or without holes failed the same as specimen

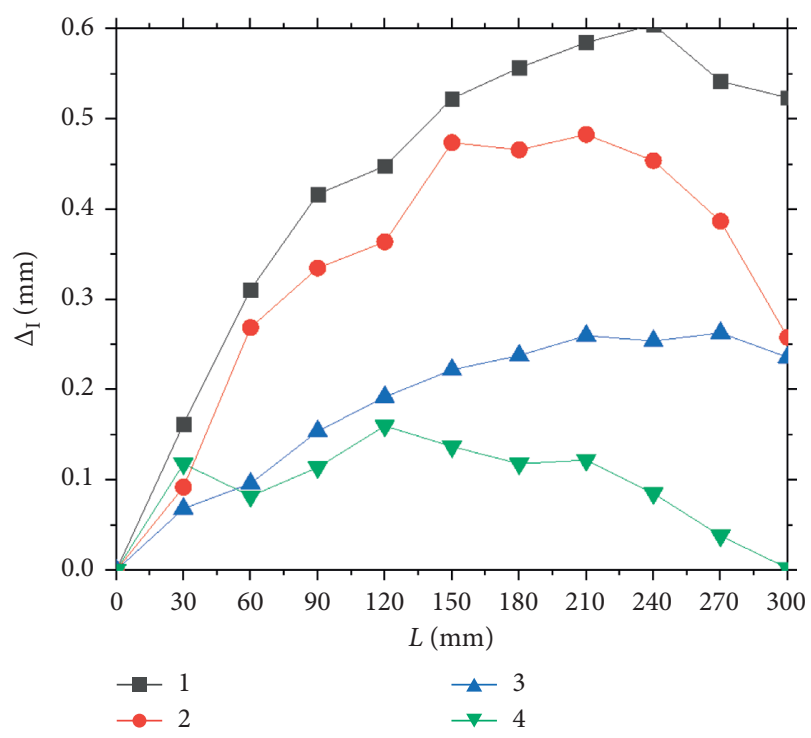

FIgURE 4: Initial imperfections of specimen C9008-03-CH3-1.

C9008-03-CH3-1. For specimen C9008-03-RH6-1 with large holes, the local buckling in the web (Figure $7(\mathrm{a})$ ), flange (Figure 7(b)), and lip (Figure 7(c)) can be observed with the increase of loading. The specimens failed with the distortional buckling (see Figure $7(\mathrm{~d})$ ) because the large hole in the web decreased the torsional stiffness of the web. The other specimens with large holes failed the same as specimen 


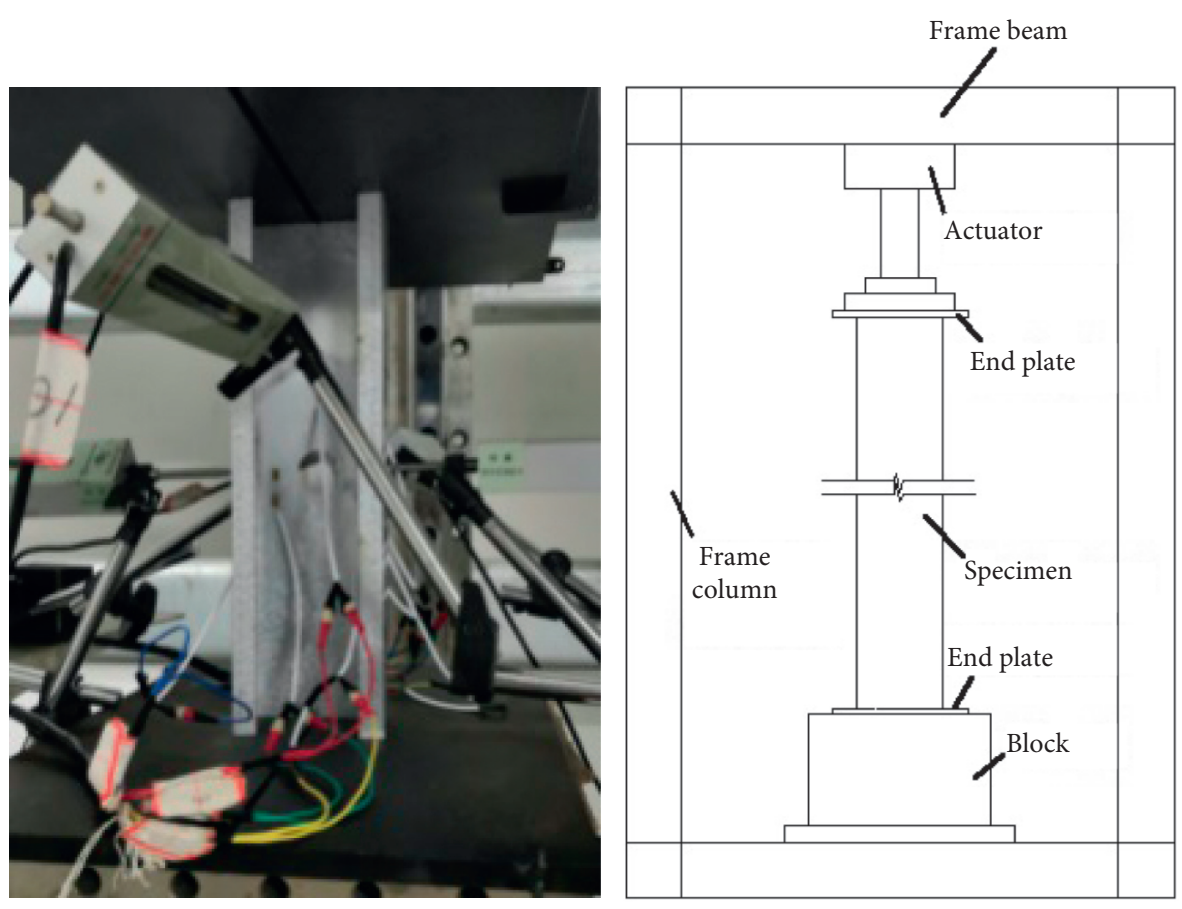

Figure 5: Test setup.

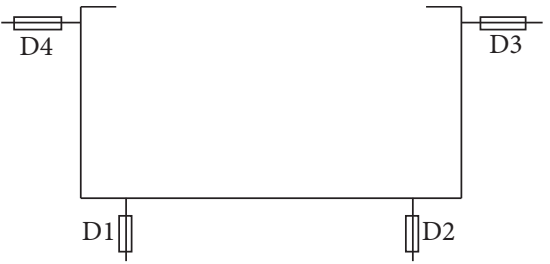

(a)

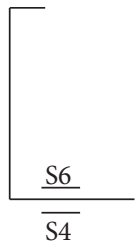

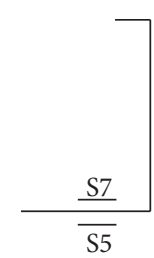

(d)

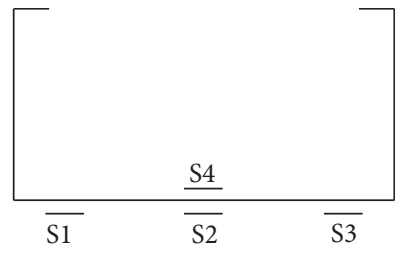

(b)

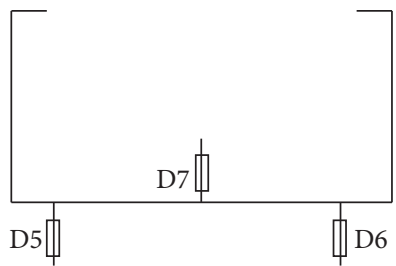

(e)

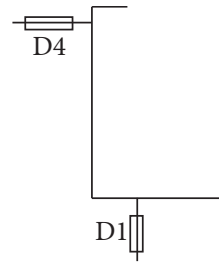

(c)

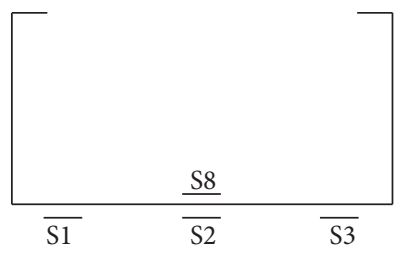

(f)

FIgURE 6: Instrumentation arrangement. (a) Position transducers for the specimen without holes. (b) Strain gauges for the specimen without holes. (c) Position transducers at midheight for the specimen with holes. (d) Strain gauges at midheight for the specimen with holes. (e) Position transducers at about $50 \mathrm{~mm}$ higher than the midheight for the specimen with holes. (f) Strain gauges at about $100 \mathrm{~mm}$ higher than the midheight for the specimen with holes.

TABLE 3: Mean value of coupon tests.

\begin{tabular}{lcccc}
\hline$t(\mathrm{~mm})$ & $E(\mathrm{MPa})$ & $f_{0.2}(\mathrm{MPa})$ & $F_{u}(\mathrm{MPa})$ & $\varepsilon_{u}(\%)$ \\
\hline 0.80 & $2.15 \times 10^{5}$ & 593 & 600 & 7.65 \\
1.00 & $2.13 \times 10^{5}$ & 618 & 629 & 9.46 \\
\hline
\end{tabular}

C9008-03-RH6-1. We need to note that the whole local buckling including holes was observed for specimens with small holes (see Figure 9(e)), but the specimens with large holes showed the local buckling of the plate strip adjacent to holes (see Figure 7(e)). The comparisons on buckling failure modes for specimens with different hole dimensions and hole types are depicted in Figure 8. It can be found that the buckling deformation would increase with the increase of the dimension of holes because the presence of holes decreases the torsional constraint of the web to the flange.

3.1.2. Section C10010 Series. The typical buckling modes of specimens for section C10010 series are illustrated in Figure 10 (specimen C10010-05-CH3-1) and Figure 11 (specimen C10010-05-RH41-1). All specimens failed in the interaction of distortional buckling and local buckling and 
TABLE 4: Comparison of buckling modes and ultimate capacities of stud columns with holes.

\begin{tabular}{|c|c|c|c|c|c|c|c|c|}
\hline Specimen & $\begin{array}{l}\text { Test buckling } \\
\text { mode }\end{array}$ & $\begin{array}{l}\text { FEA buckling } \\
\text { mode }\end{array}$ & $P_{t}(\mathrm{kN})$ & $\begin{array}{c}\text { Decreasing of load capacities } \\
(\%)\end{array}$ & $P_{A}(\mathrm{kN})$ & $P_{M}(\mathrm{kN})$ & $P_{t} / P_{A}$ & $P_{M} / P_{t}$ \\
\hline C9008-03-NH-1 & $L$ & $L$ & 41.13 & - & 41.97 & 39.48 & 0.98 & 0.96 \\
\hline C9008-03-NH-2 & $L$ & $L$ & 42.22 & - & 43.53 & 39.26 & 0.97 & 0.94 \\
\hline С9008-03-СН3-1 & $L$ & $L$ & 39.97 & 4.09 & 41.21 & 39.17 & 0.97 & 0.98 \\
\hline С9008-03-СН3-2 & $L$ & $L$ & 40.23 & 3.47 & 41.05 & 39.02 & 0.98 & 0.97 \\
\hline C9008-03-CH5-1 & $L$ & $L$ & 38.85 & 6.78 & 40.05 & 38.46 & 0.97 & 0.99 \\
\hline C9008-03-CH5-2 & $L$ & $L$ & 38.71 & 7.11 & 41.12 & 38.67 & 0.99 & 0.95 \\
\hline C9008-03-CH7-1 & $L+D$ & $L+D$ & 34.77 & 16.57 & 35.81 & 32.44 & 0.95 & 0.94 \\
\hline C9008-03-CH7-2 & $L+D$ & $L+D$ & 35.49 & 14.84 & 37.88 & 34.39 & 0.94 & 0.96 \\
\hline C9008-03-RH2-1 & $L$ & $L$ & 39.87 & 4.33 & 43.16 & 38.94 & 0.97 & 0.93 \\
\hline C9008-03-RH2-2 & $L$ & $L$ & 39.52 & 5.17 & 41.60 & 38.73 & 0.95 & 0.98 \\
\hline C9008-03-RH4-1 & $L$ & $L$ & 39.24 & 5.84 & 40.04 & 38.06 & 0.98 & 0.97 \\
\hline C9008-03-RH4-2 & $L$ & $L$ & 38.96 & 6.51 & 43.16 & 37.14 & 0.94 & 0.94 \\
\hline C9008-03-RH6-1 & $L+D$ & $L+D$ & 35.91 & 13.83 & 37.80 & 34.11 & 0.95 & 0.95 \\
\hline C9008-03-RH6-2 & $L+D$ & $L+D$ & 36.14 & 13.28 & 36.88 & 33.97 & 0.98 & 0.94 \\
\hline C10010-05-NH-1 & $L+D$ & $L+D$ & 52.31 & - & 53.70 & 50.22 & 0.96 & 0.96 \\
\hline C10010-05-NH-2 & $L+D$ & $L+D$ & 52.48 & - & 54.67 & 49.33 & 0.96 & 0.94 \\
\hline C10010-05-CH3-1 & $L+D$ & $L+D$ & 51.68 & 1.17 & 52.76 & 49.61 & 0.98 & 0.96 \\
\hline C10010-05-CH3-2 & $L+D$ & $L+D$ & 51.19 & 2.11 & 52.77 & 49.65 & 0.97 & 0.97 \\
\hline C10010-05-CH5-1 & $L+D$ & $L+D$ & 51.01 & 2.45 & 53.39 & 47.95 & 0.96 & 0.94 \\
\hline C10010-05-CH5-2 & $L+D$ & $L+D$ & 50.54 & 3.35 & 53.20 & 48.01 & 0.95 & 0.95 \\
\hline C10010-05-CH7-1 & $L+D$ & $L+D$ & 45.53 & 12.91 & 48.44 & 41.89 & 0.94 & 0.92 \\
\hline C10010-05-CH7-2 & $L+D$ & $L+D$ & 45.76 & 12.47 & 47.67 & 42.56 & 0.96 & 0.93 \\
\hline C10010-05-RH2-1 & $L+D$ & $L+D$ & 51.95 & 0.66 & 53.01 & 50.39 & 0.98 & 0.97 \\
\hline C10010-05-RH2-2 & $L+D$ & $L+D$ & 51.48 & 1.56 & 52.53 & 47.36 & 0.98 & 0.92 \\
\hline C10010-05-RH4-1 & $L+D$ & $L+D$ & 51.10 & 2.28 & 53.23 & 50.08 & 0.96 & 0.98 \\
\hline C10010-05-RH4-2 & $L+D$ & $L+D$ & 50.22 & 3.96 & 51.77 & 47.71 & 0.97 & 0.95 \\
\hline C10010-05-RH6-1 & $L+D$ & $L+D$ & 46.19 & 11.65 & 49.14 & 44.80 & 0.94 & 0.97 \\
\hline C10010-05-RH6-2 & $L+D$ & $L+D$ & 44.12 & 15.60 & 45.96 & 41.47 & 0.96 & 0.94 \\
\hline \multicolumn{7}{|c|}{ Average } & 0.9639 & 0.9571 \\
\hline \multirow{2}{*}{\multicolumn{7}{|c|}{$\begin{array}{l}\text { Standard deviation } \\
\text { Coefficient of variation }\end{array}$}} & 0.0147 & 0.0186 \\
\hline & & & & & & & 0.0153 & 0.0194 \\
\hline
\end{tabular}

displayed a distortional buckling half-wave and many local buckling half-waves. For specimen C10010-05-CH3-1 with small holes, the buckling in web (Figure 12(a)) and local buckling in flange (Figure 12(b)) were observed with the increase of loading because the web and flange of these specimens have a large width-to-thickness ratio. Then, distortional buckling (Figure 12(c)) gradually occurred with the increase of loading. The specimen finally collapsed for the plastic resulted from the large buckling deformation (Figure 12(d)). The other specimens with small holes or without holes failed the same as specimen C10010-05-CH31. For specimen C10010-05-RH4-1 with large holes, the specimens displayed local buckling in the web and distortional buckling (Figure 10(a)) simultaneously. Then local buckling can be found in the flanges (Figure 10(b)). Finally, the specimen collapsed for the plastic crush (Figure 10(c)). The other specimens with large holes failed the same as specimen C10010-05-RH4-1. The same buckling mode for specimens with rectangular holes can be observed as the specimens with circular holes. The specimens with small holes showed the whole local buckling including holes (see Figure 12(e)), and the specimens with large holes displayed the local buckling of the plate strip adjacent to holes (see Figure $10(\mathrm{~d})$ ). The comparisons on buckling failure modes for specimens with different dimensions and types of holes are depicted in Figure 11. It can be found that the distortional buckling deformation increases with the increase of the dimension of holes because the hole in the web decreases the torsional constraint of the web to the flange.

3.2. Strain Analysis. The typical load and strain curves for specimens with different holes are illustrated in Figures 13 and 14 , in which $P$ and $\varepsilon$ represent the applied load and the strain variations. The local buckling occurred when $P$ reached $26.5 \mathrm{kN}$ and $28 \mathrm{kN}$ for specimen C9008-03-CH31 for the plate strip adjacent to the hole and the web about $50 \mathrm{~mm}$ higher than midheight as depicted in Figure 13. The strain fast increased with the increase of loading after local buckling. For specimen C9008-03-CH71, the plate strip adjacent to the hole and the web about $50 \mathrm{~mm}$ higher than midheight displayed the local buckling when $P$ reached $12.8 \mathrm{kN}$ and $21.3 \mathrm{kN}$ as shown in Figure 14. The comparison results indicated that the plate strip adjacent to the hole buckled earlier than other parts. The comparison between Figures 13 and 14 showed that the specimen with large holes displayed the local buckling earlier and higher postbuckling strength reserve than the specimen with small holes. 


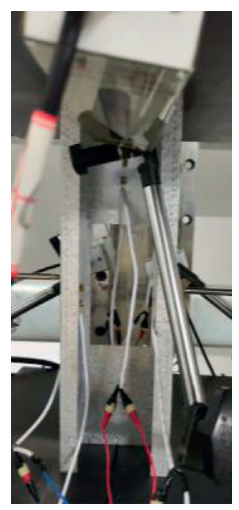

(a)

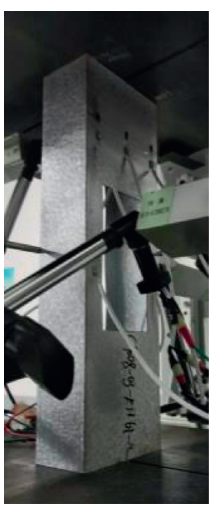

(b)

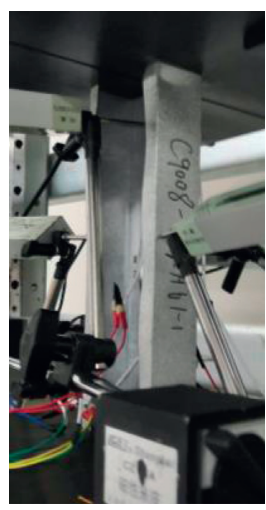

(c)

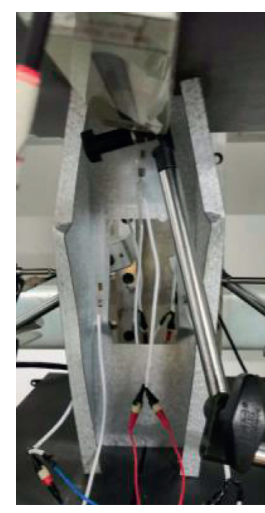

(d)

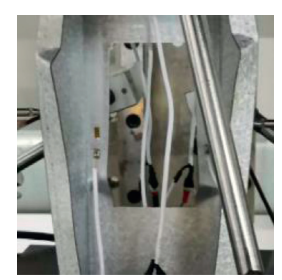

(e)

Figure 7: Buckling mode of specimen C9008-03-RH6-1. (a) Local buckling in the web. (b) Local buckling in the flange. (c) Local buckling in the lip. (d) Distortional buckling. (e) Local buckling of the plate strip adjacent to holes.

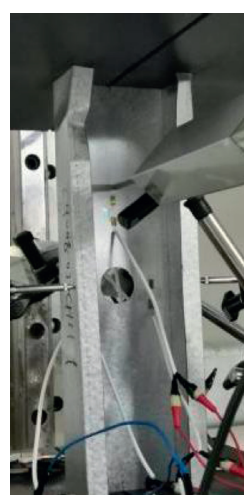

$d / b=0.3$

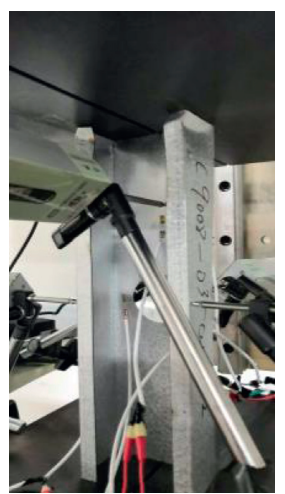

$d / b=0.5$

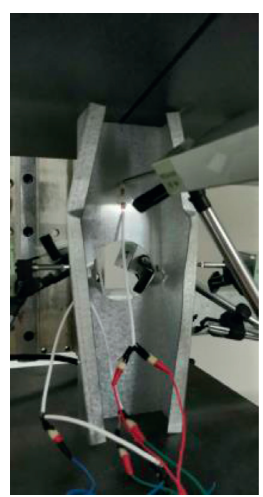

$d / b=0.7$

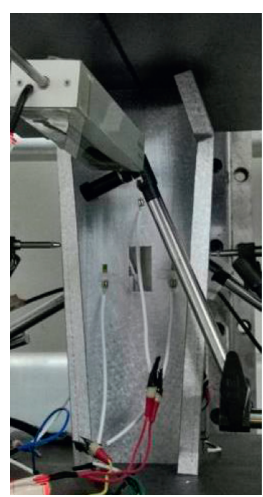

$H_{h} / b=0.2$

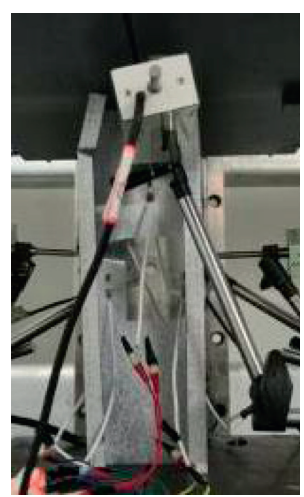

$H_{h} / b=0.4$

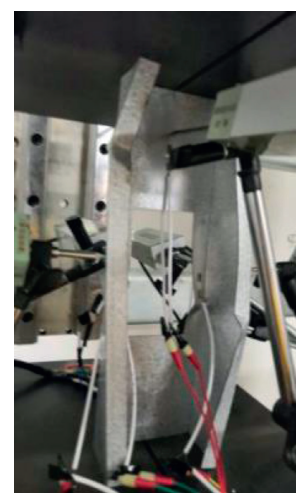

$H_{h} / b=0.6$

(a)

FIGURE 8: Comparison of the buckling mode for section 9008 series with different dimensions of holes. (a) Specimens with circular holes. (b) Specimens with rectangular holes.

3.3. Load-Axial Displacement Curve Analysis. Load and axial displacement curves for section C9008 series with circular holes and section 10010 series with circular holes are illustrated in Figure 15. As shown in Figure 15, the load and the axial displacement kept linearity in the initial period of loading; then, it changed the nonlinear relate when the buckling occurred. The load decreased instantaneously as soon as the specimens were crushed. Meanwhile, the comparisons on load-displacement curves of section C9008 series and section 10010 series with various dimensions of circular holes indicate that the load capacity and stiffness of stud columns with holes decrease with the increase of the dimension of holes.

3.4. Ultimate Strength Analysis. Experimental ultimate load capacities for all stud columns with holes are summarized in Table 4, in which $P_{\mathrm{t}}$ was the tested ultimate load. The following results can be obtained from Table 4: the ultimate load capacities decreased $3 \%-8 \%$ and $1 \%-4 \%$ for section
C9008 series and section C10010 series when the ratio of circular hole diameter to web height increased from 0 to 0.3 and 0.5 and the ratio of rectangular hole height to web height increased from 0 to 0.2 and 0.4 , respectively. The ultimate load capacities reduced about $15 \%$ when the circular hole diameter-to-web height ratio changed from 0 to 0.7 and the rectangular hole height-to-web height ratio changed from 0 to 0.6. The comparison results indicated the increase of the dimension of holes can result in a decrease in the ultimate load capacity of the stud column with holes. The large hole had a great effect on the decrease of ultimate strength of the stud column with holes.

\section{Verification of the FEM and Parametric Study}

4.1. Verification of the Finite Element Model. The finite element analysis program ABAQUS [15] was used to simulate the compression behavior of the tested stud columns and make a further parametric study on the CFS lipped channel section stud columns with holes. The developed FEM and 


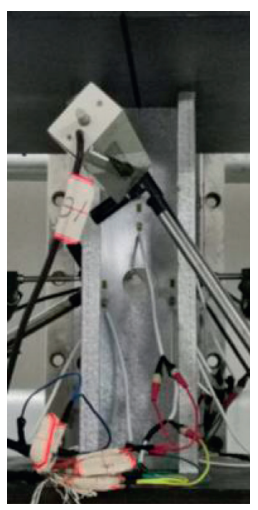

(a)

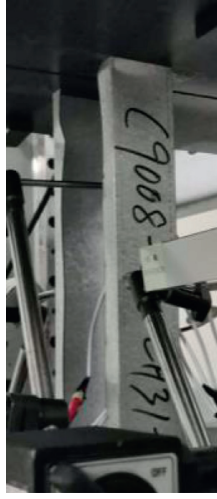

(b)

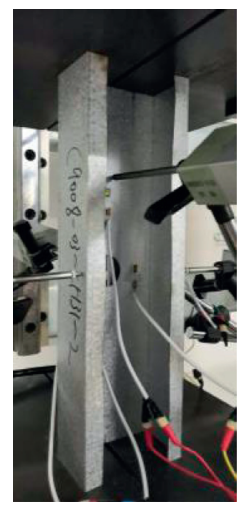

(c)

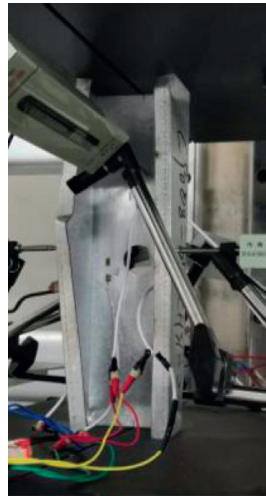

(d)

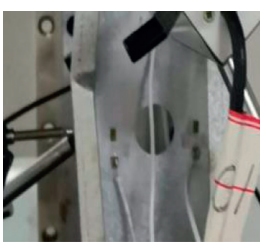

(e)

FIGURE 9: Buckling mode of specimen C9008-03-CH3-1. (a) Local buckling in the web. (b) Local buckling in the flange. (c) Local buckling in the lip. (d) Plastic crush. (e) Local buckling including holes.

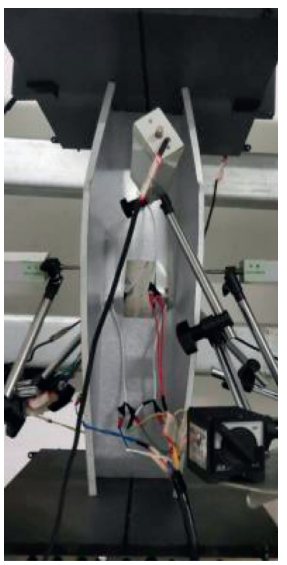

(a)

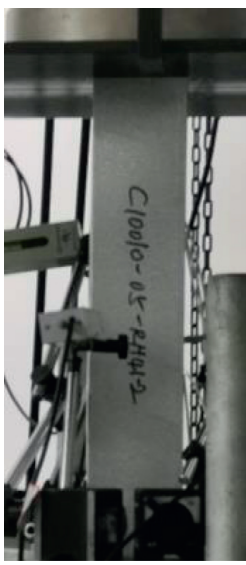

(b)

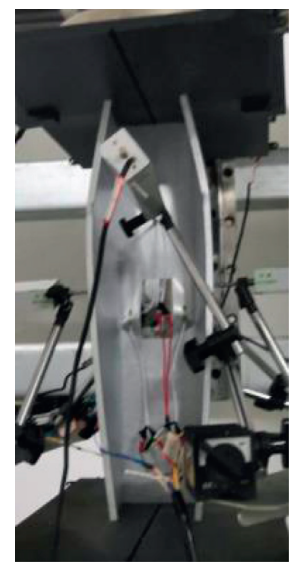

(c)

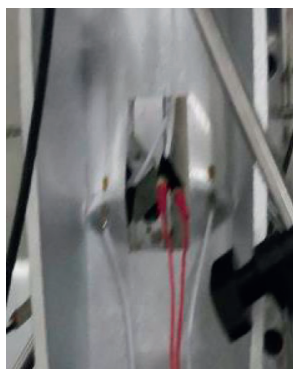

(d)

Figure 10: Buckling mode of specimen C10010-05-RH4-1. (a) Local buckling in web + distortional buckling. (b) Local buckling in the flange. (c) Plastic crush. (d) Local buckling of the plate strip adjacent to holes.

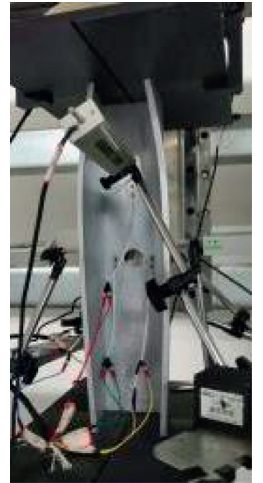

$d / b=0.3$

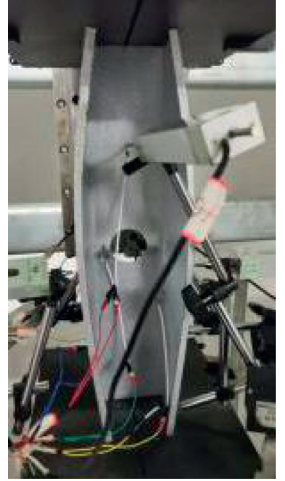

$d / b=0.5$

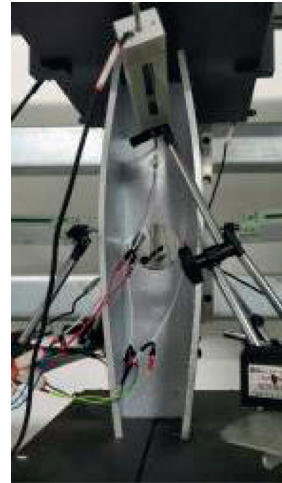

$d / b=0.7$

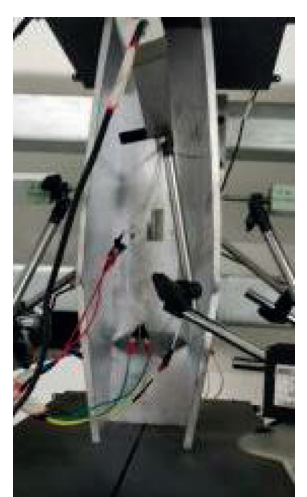

$H_{h} / b=0.2$

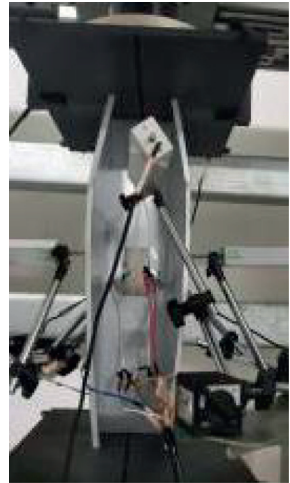

$H_{h} / b=0.4$

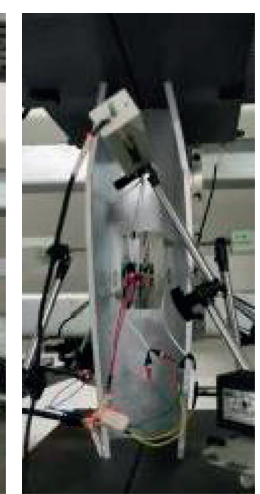

$H_{h} / b=0.6$

(a)

FIGURE 11: Comparison of the buckling mode for section 10010 series with different dimensions of holes. (a) Specimens with circular holes. (b) Specimens with rectangular holes. 


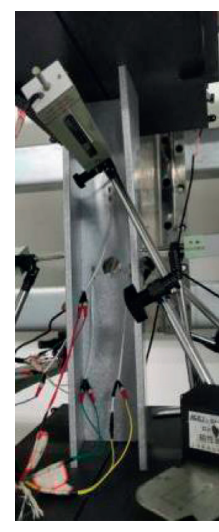

(a)

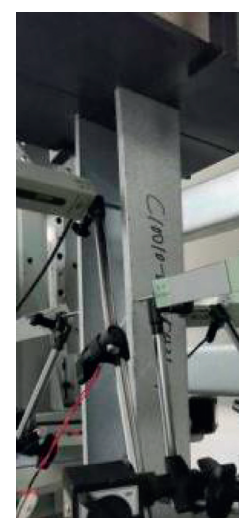

(b)

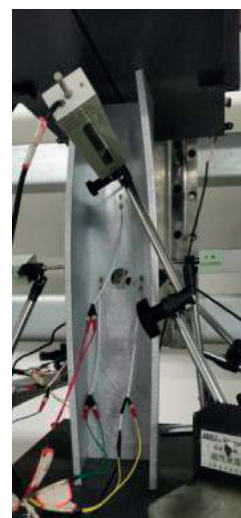

(c)

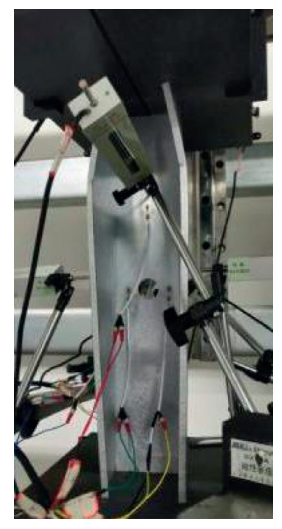

(d)

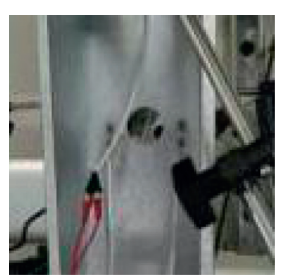

(e)

Figure 12: Buckling mode of specimen C10010-05-CH3-1. (a) Local buckling in the web. (b) Local buckling in the flange. (c) Distortional buckling. (d) Plastic crush. (e) Local buckling including holes.

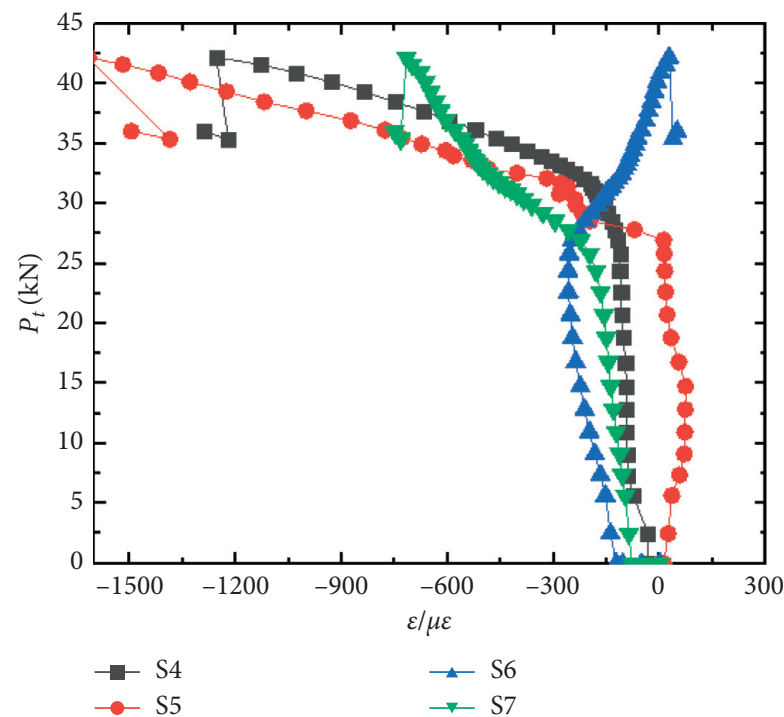

(a)

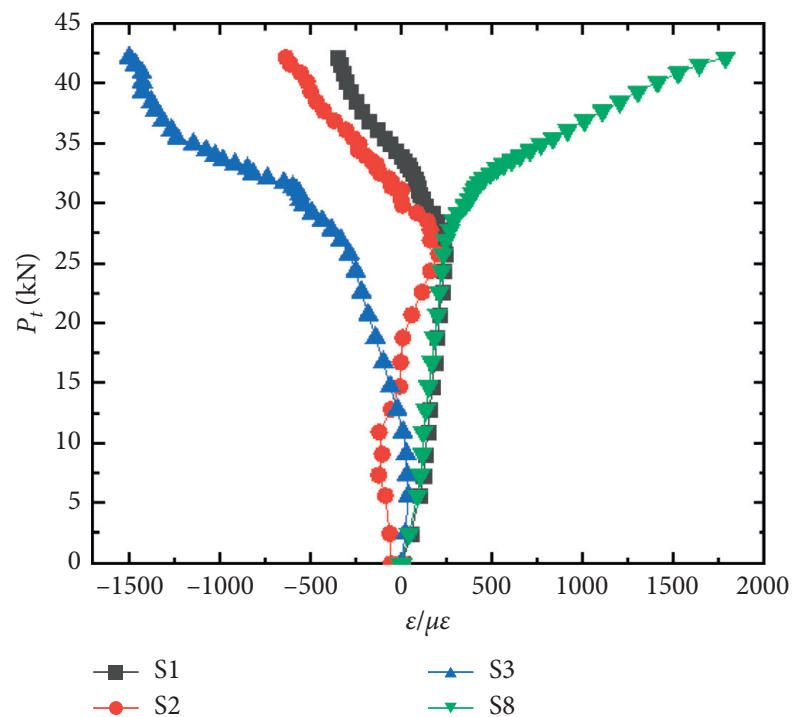

(b)

FIgURE 13: Load and strain curves for specimen C9008-03-CH31. (a) Midheight. (b) About 50 mm higher than midheight.

analysis progress can be found in [15]. A comparison of the buckling modes and the load-carrying capacities between test results and FEA results is shown in Table 4 , in which $P_{A}$ represents the load-carrying capacities of specimens obtained by FEA. The mean value and the corresponding coefficient of variation of the ratio of test results to FEA results $\left(P_{t} / P_{A}\right)$ are 0.9639 and 0.0153 . Meanwhile, it can be observed that the deviations between FEA results and the test results are less than $5 \%$. The failure modes of the section C9008 series $(d / b=0,0.3$, and 0.7$)$ obtained from FEA are also compared with the tests as shown in Figure 16; the local buckling for section C9008 $(d / b=0,0.3)$ and the interaction of local buckling and distortional buckling for section C9008 $(d / b=0.7)$ can be seen. The comparisons on buckling modes show very good agreement between the tests and FEA results. The finite element analysis load-displacement curves of the section C9008 series with circular holes and the section
C10010 series with rectangular holes carried out by the FE match well with the test result as plotted in Figures 17 and 18. Therefore, these analysis results indicate that the FEA results are accurate in terms of failure mode, ultimate strength, and load-displacement curve. FEM developed can be used to further analyze the buckling behavior of CFS lipped channel stud columns with holes.

4.2. Finite Element Parametric Study. The verified FEM was used to investigate the effect of the dimension of holes on the ultimate strength of stud columns. The normal section C7020 and section C16020 were selected to analyze. The nominal dimensions of cross section are shown in Table 5 . The maximum magnitude of the initial imperfection was equal to $L / 750$ according to the Chinese standard [1]. The ultimate strengths of the stud columns with holes completed by using FEA are listed in Table 5. As shown in Table 5, the 


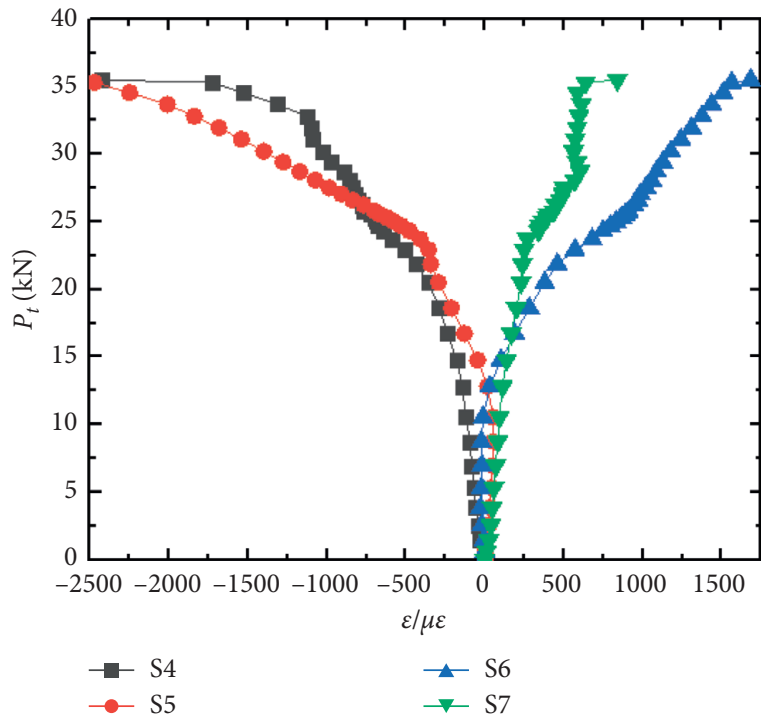

(a)

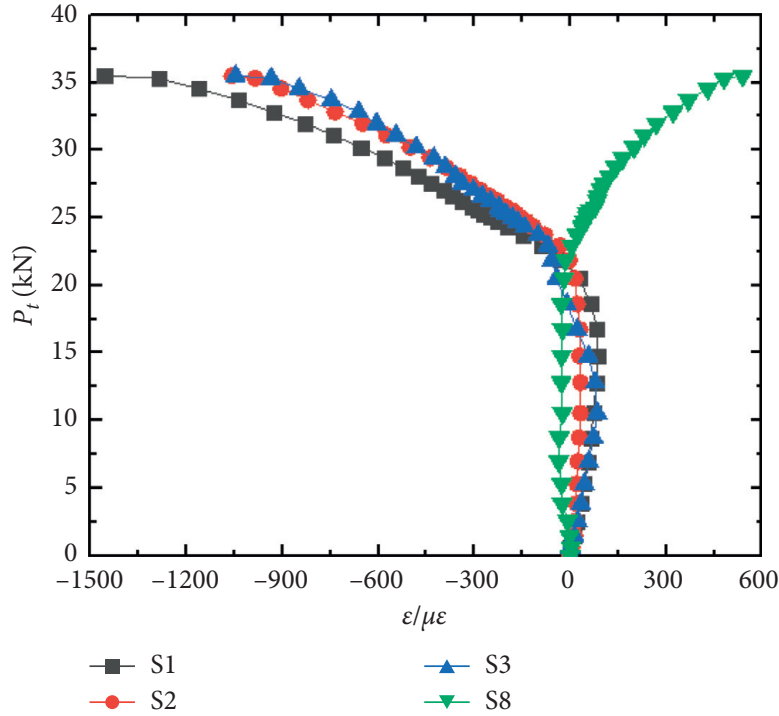

(b)

FIgURE 14: Load and strain curves for specimen C9008-03-CH71. (a) Midheight. (b) About 50 mm higher than midheight.

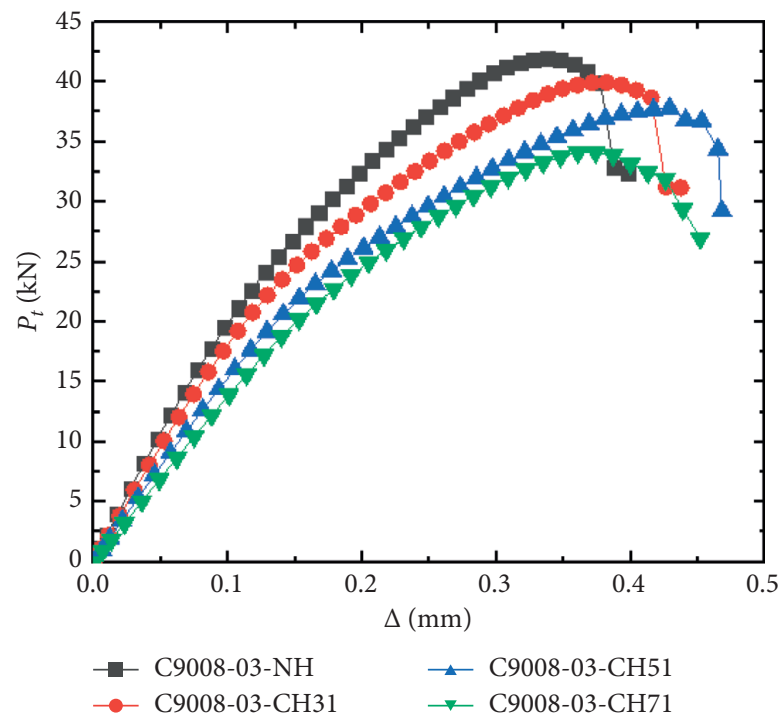

(a)

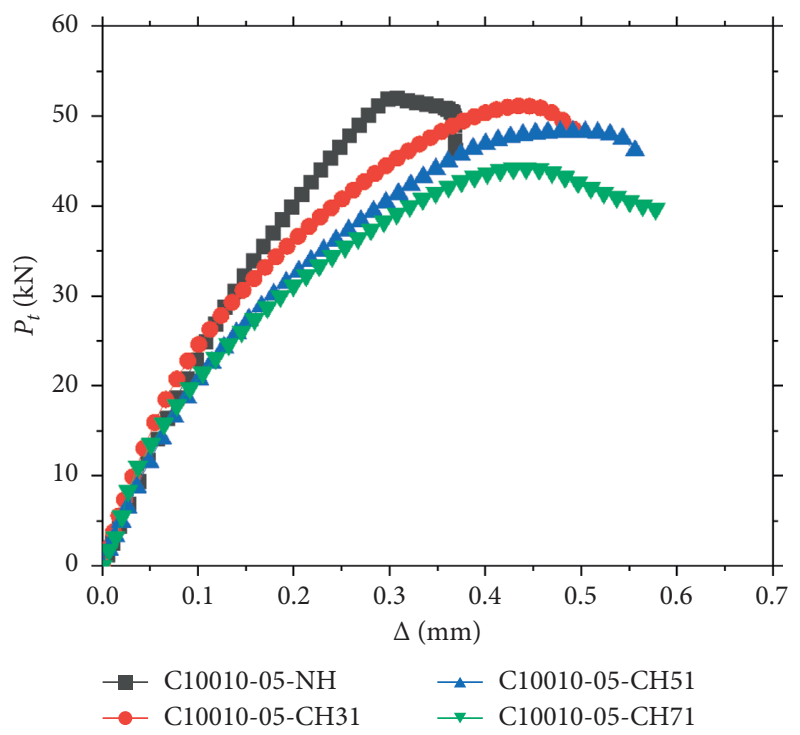

(b)

Figure 15: Comparison of load and axial displacement curves for section C9008 series. (a) Section C9008 series. (b) Section C10010 series.

ultimate strengths of CFS stud columns with holes decrease with the increase of dimensions of holes. The load capacity of stud columns with circular holes is slightly higher than that of stud columns with rectangular holes when the diameter of the circular hole is equal to the length of the square hole. The load capacity of stud columns will decrease with the increase of the length of rectangular holes when the heights of holes are the same, but this effect is not very obvious when the ratio of the length to the height of holes changes from 1 to 2 .

\section{Design Method}

The effective width method is an efficient traditional mean to consider the postlocal buckling and used in many specifications to determine the ultimate strength of CFS members in the world. Therefore, the EWM is considered to predict the ultimate strength of the CFS stud columns with holes by considering the effect of holes on the elastic buckling coefficient of the plate in this paper. 


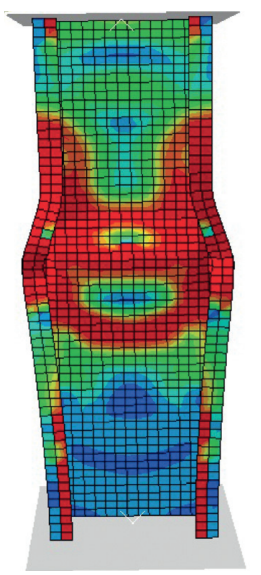

(a)

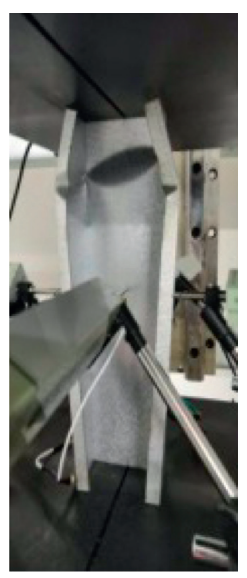

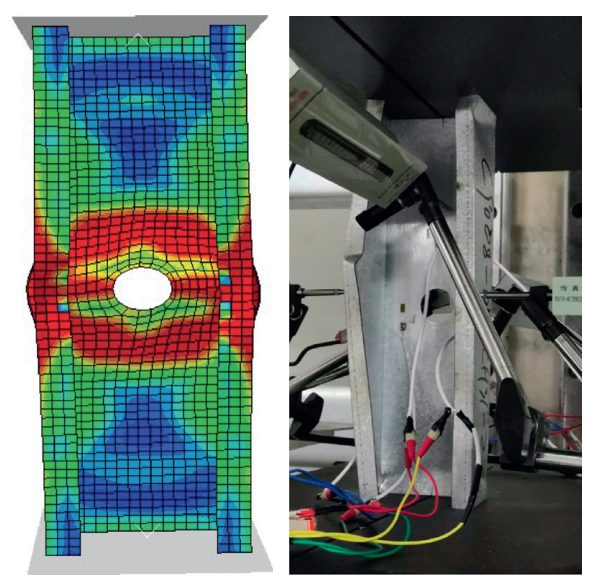

(b)
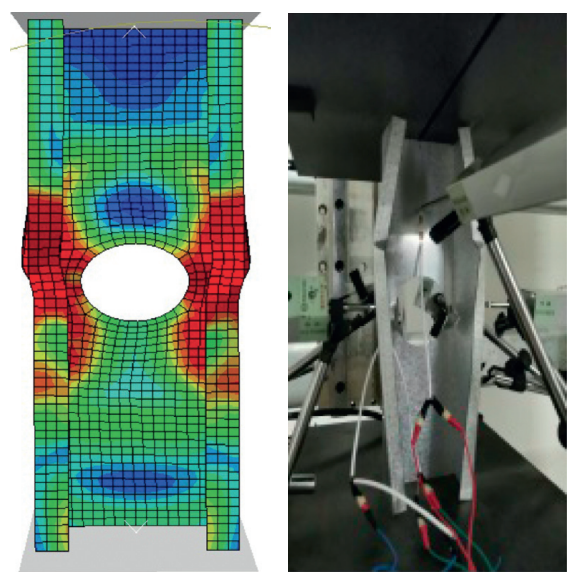

(c)

FIgURE 16: Comparison of buckling modes between test and FEA for section C9008 series. (a) $d / h=0$. (b) $d / h=0.3$. (c) $d / h=0.7$.
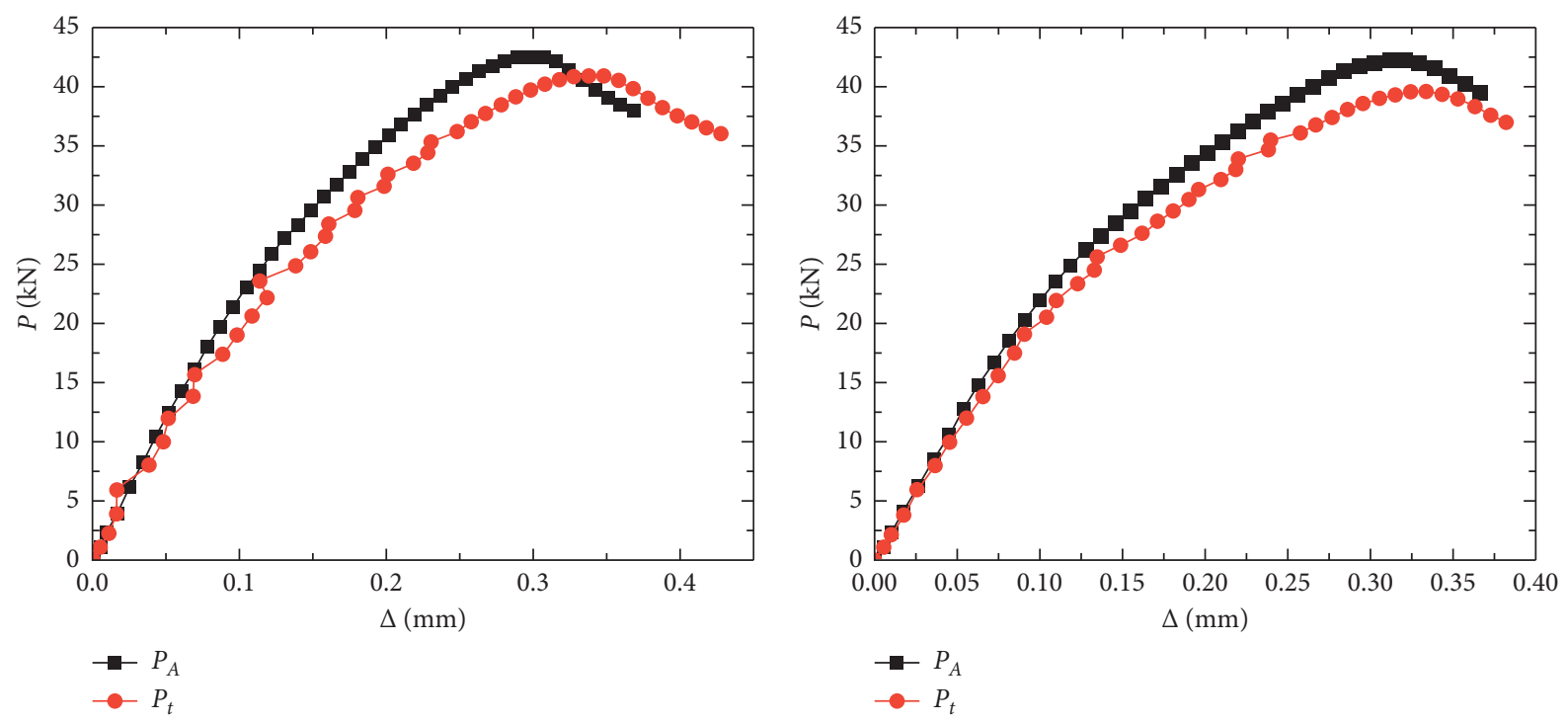

(a)

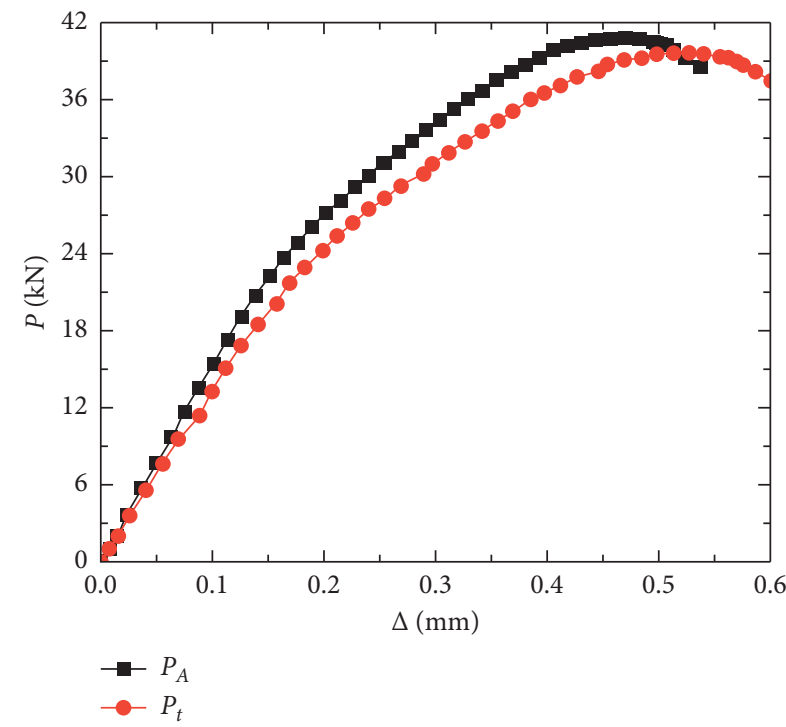

(c)

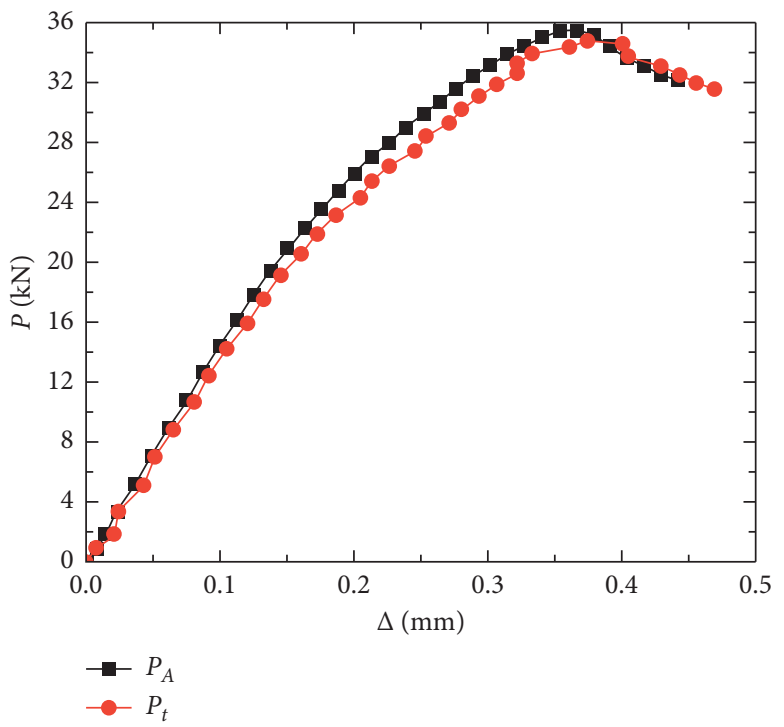

(d)

Figure 17: Comparison of load-axial displacement curves between test and FEA for section C9008 series. (a) C9008-03-NH. (b) C9008-03CH3. (c) C9008-03-CH5. (d) C9008-03-CH7. 

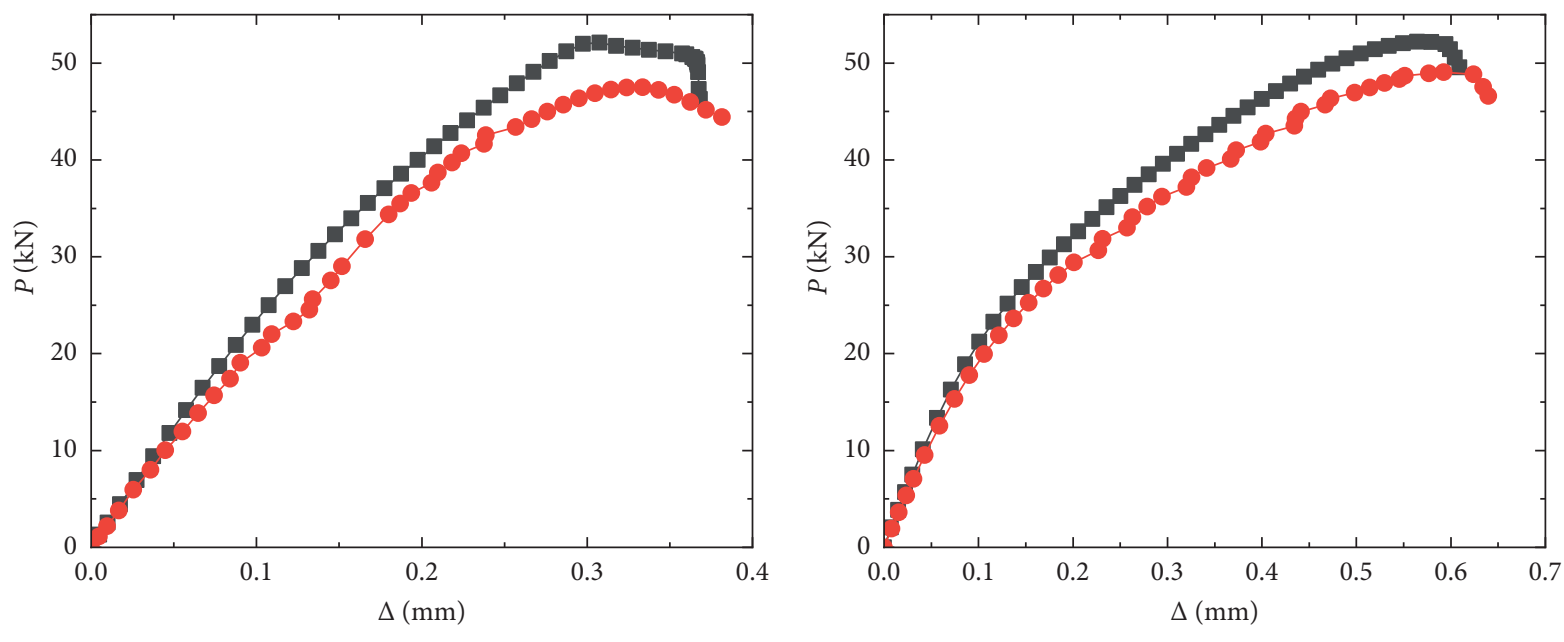

$$
\begin{aligned}
& -P_{A} \\
& -P_{t}
\end{aligned}
$$

$$
\begin{aligned}
& \rightarrow-P_{A} \\
& \rightarrow-P_{t}
\end{aligned}
$$

(a)

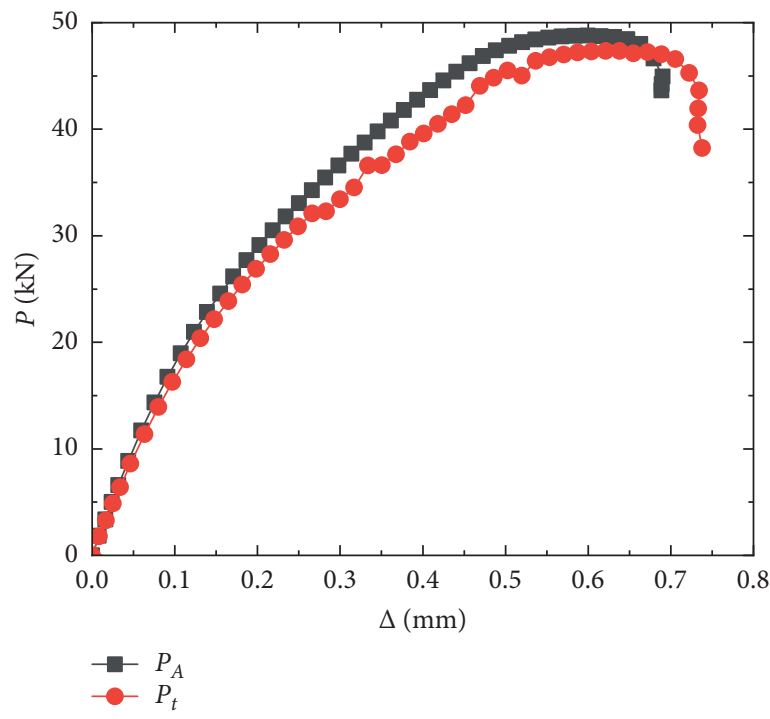

(c)

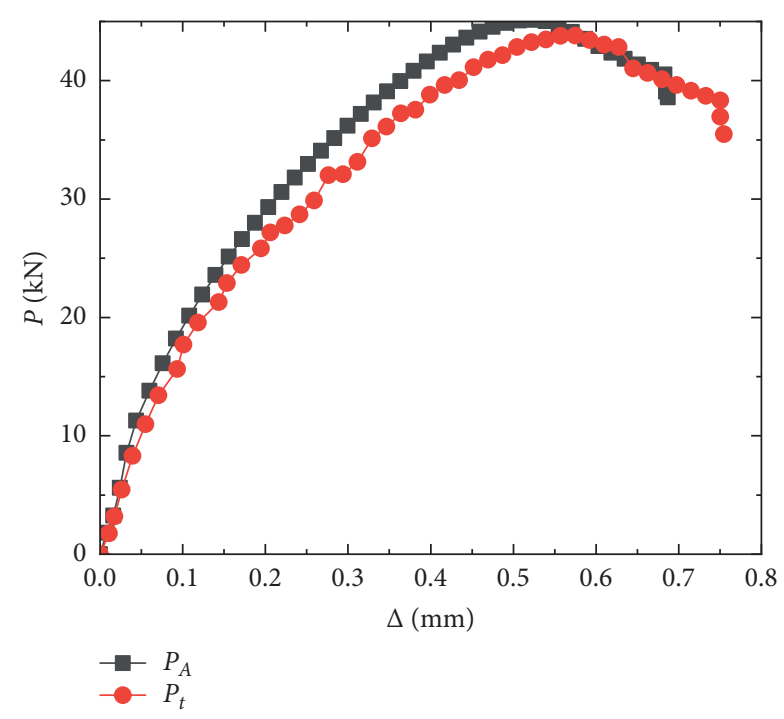

(d)

Figure 18: Comparison of load-axial displacement curves between test and FEA for section C10010 series. (a) C10010-05-NH. (b) C1001005-RH2. (c) C10010-05-RH4. (d) C10010-05-RH6.

5.1. Effective Width Method. The ultimate strength of CFS stud columns with holes under axial compression can be predicted as follows:

$$
P_{M}=A_{e} \cdot f_{y} \leq A_{\text {net }} f_{y},
$$

where $P_{M}$ is the ultimate strength of the CFS stud column; $f_{y}$ is the yield strength; $A_{\text {net }}$ is the net cross-sectional area; $A_{e}$ is the effective cross-sectional area which can be predicted by calculating the effective width of the cross section.

The effective width of the element of CFS members should be determined by using [1]

$$
\frac{b_{e}}{t}= \begin{cases}\frac{b_{c}}{t} & \frac{b}{t} \leq 18 \alpha \rho \\ \left(\sqrt{\frac{21.8 \alpha \rho}{b / t}}-0.1\right) \frac{b_{c}}{t} & 18 \alpha \rho<\frac{b}{t}<38 \alpha \rho, \\ \frac{25 \alpha \rho}{b / t} & \frac{b}{t} \geq 38 \alpha \rho\end{cases}
$$

where $b_{c}$ is the width of the compressed zone for the plate, $b$ is the width of the plate, and $t$ is the thickness of the plate. 
TABLE 5: Ultimate strengths of section C7020-02 series and section C16020-05 series by using FEA and the modified EWM.

\begin{tabular}{|c|c|c|c|c|c|c|c|c|}
\hline Stud columns & $h$ & $b$ & $a$ & $\mathrm{t}$ & $H_{L} / H_{H}$ & $P_{A}(\mathrm{kN})$ & $P_{M}(\mathrm{kN})$ & $P_{M} / P_{A}$ \\
\hline C7020-02-NH & & & & & - & 149.65 & 140.67 & 0.94 \\
\hline С7020-02-CH3 & & & & & - & 143.51 & 139.2 & 0.97 \\
\hline C7020-02-CH5 & & & & & & 103.98 & 98.78 & 0.95 \\
\hline C7020-02-CH7 & & & & & & 85.65 & 78.80 & 0.92 \\
\hline C7020-02-RH2 & & & & & 2 & 145.08 & 139.28 & 0.96 \\
\hline C7020-02-RH4 & & & & & & 141.58 & 137.33 & 0.97 \\
\hline C7020-02-RH6 & 70 & 30 & 12 & 2 & & 97.3 & 95.8 & 0.98 \\
\hline C7020-02-RH2-1 & & & & & 1 & 142.35 & 140.23 & 0.99 \\
\hline C7020-02-RH3-1 & & & & & & 142.10 & 139.2 & 0.98 \\
\hline C7020-02-RH4-1 & & & & & & 140.78 & 138.9 & 0.99 \\
\hline C7020-02-RH5-1 & & & & & & 99.53 & 98.78 & 0.99 \\
\hline C7020-02-RH6-1 & & & & & & 98.87 & 97.2 & 0.98 \\
\hline C7020-02-RH7-1 & & & & & & 82.36 & 78.80 & 0.96 \\
\hline C16020-05-NH & & & & & - & 203.89 & 191.66 & 0.94 \\
\hline C16020-05-CH3 & & & & & - & 193.62 & 189.75 & 0.98 \\
\hline C16020-05-CH5 & & & & & & 159.27 & 148.12 & 0.93 \\
\hline C16020-05-CH7 & & & & & & 135.76 & 124.90 & 0.92 \\
\hline C16020-05-RH2 & & & & & 2 & 195.52 & 189.65 & 0.97 \\
\hline C16020-05-RH4 & & & & & & 193.22 & 185.49 & 0.96 \\
\hline C16020-05-RH6 & 160 & 60 & 20 & 2 & & 138.61 & 132.19 & 0.95 \\
\hline C16020-05-RH2-1 & & & & & 1 & 193.56 & 190.37 & 0.98 \\
\hline C16020-05-RH3-1 & & & & & & 193.05 & 189.75 & 0.98 \\
\hline C16020-05-RH4-1 & & & & & & 190.88 & 187.25 & 0.98 \\
\hline C16020-05-RH5-1 & & & & & & 152.34 & 148.12 & 0.97 \\
\hline C16020-05-RH6-1 & & & & & & 136.23 & 134.66 & 0.99 \\
\hline C16020-05-RH7-1 & & & & & & 127.12 & 124.90 & 0.98 \\
\hline \multicolumn{8}{|c|}{ Average } & 0.9663 \\
\hline \multirow{2}{*}{\multicolumn{8}{|c|}{$\begin{array}{l}\text { Standard deviation } \\
\text { Coefficient of variation }\end{array}$}} & 0.0179 \\
\hline & & & & & & & & 0.0185 \\
\hline
\end{tabular}

For CFS axial stud columns, $b_{c}=b, \quad \alpha=1$, $\rho=\sqrt{\left(235 k_{1} k / \varphi f_{y}\right)}, \quad k_{1}$ is the coefficient of interaction buckling, and $k$ is the buckling coefficient of the plate considering the effect of holes.

5.2. Buckling Coefficient of Plates with Holes. There are two buckling modes for the plate with holes as shown in Section 3 , namely, the whole local buckling including holes and the local buckling of the plate strip adjacent to holes. The buckling coefficient of perforated plate $k$ should consider these two buckling modes.

5.2.1. Buckling Coefficient of Plates with Circular Holes. The buckling coefficient of plates with circular holes under axial compression can be obtained by using finite element linear elastic buckling analysis as depicted in Figure 19. The curves of the buckling coefficient are divided into two parts which means two bucking modes. The critical dimension of the changing of buckling modes is 0.36 which can be analyzed using the curves of the buckling coefficient in Figure 19. When the ratio of the diameter of holes to the width of plates $(d / b)$ is less than 0.36 , the buckling coefficient of plates with circular holes under axial compression can be obtained using formula (3) which is analyzed according to the left part of the curve.

$$
k=4\left[1.06(d / b)^{2}-0.46(d / b)+1\right] .
$$

The local buckling coefficients of the plate strips adjacent to holes under axial compression are shown in Figure 20 for different length-to-width ratios when the ratio of the diameter of holes to the width of plates $(d / b)$ is more than 0.36 . The buckling coefficient of the plate strips can be determined using formula (4) which is obtained by regression analysis.

$$
k=0.425\left[\frac{2.18}{0.6\left(d / b_{1}\right)^{1.75}+0.003}+1\right]
$$

where $b_{1}$ is the width of the unstiffened plate strip adjacent to holes, $b_{1}=(b-d) / 2$.

5.2.2. Buckling Coefficient of Plates with Rectangular Holes. The buckling coefficients of plates with rectangular holes under axial compression analyzed by finite element are shown in Figure 21, in which the length to width of holes is equal to 2,4 , and 8 . It can be found that the length to width of holes has a slight effect on the buckling coefficient. So, the effect of the length to width of holes on buckling coefficients can be ignored when the buckling coefficient formula is analyzed. The curves of the buckling coefficient is divided into two parts the same as the plate with circular holes. The 


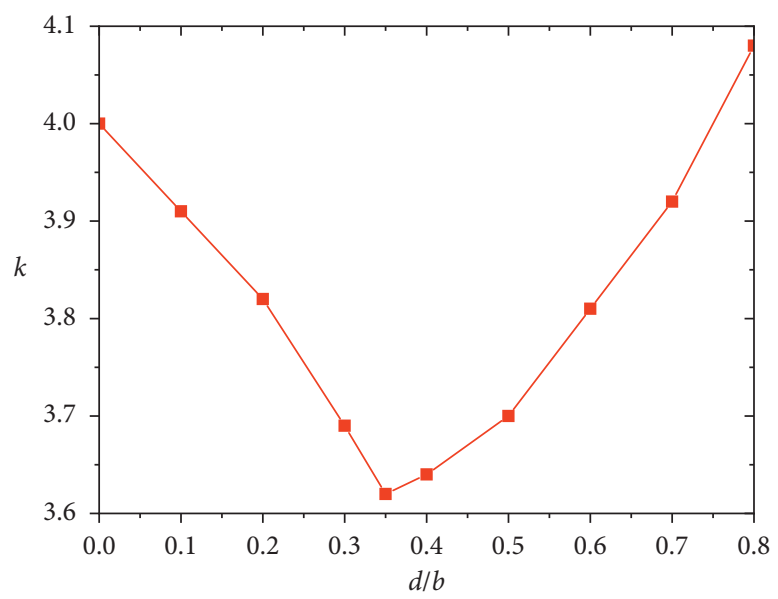

Figure 19: Buckling coefficient of plates with circular holes.

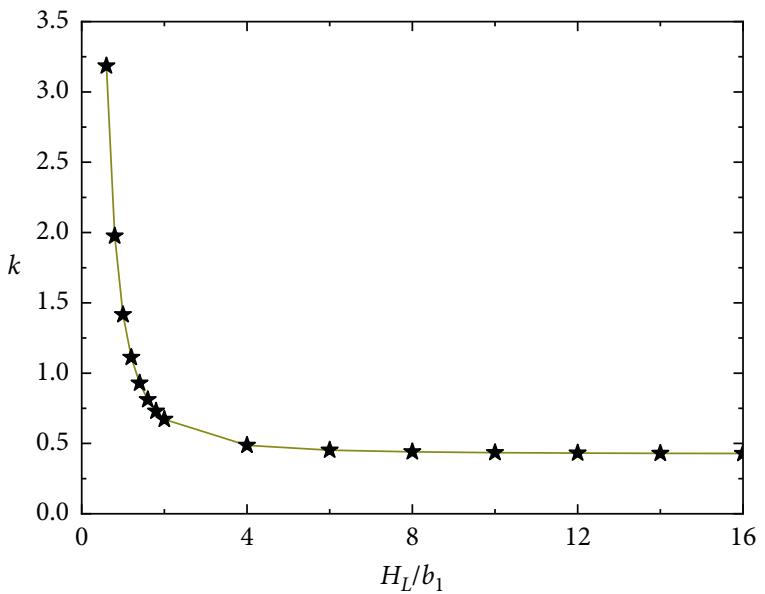

Figure 20: Buckling coefficient of the plate strip.

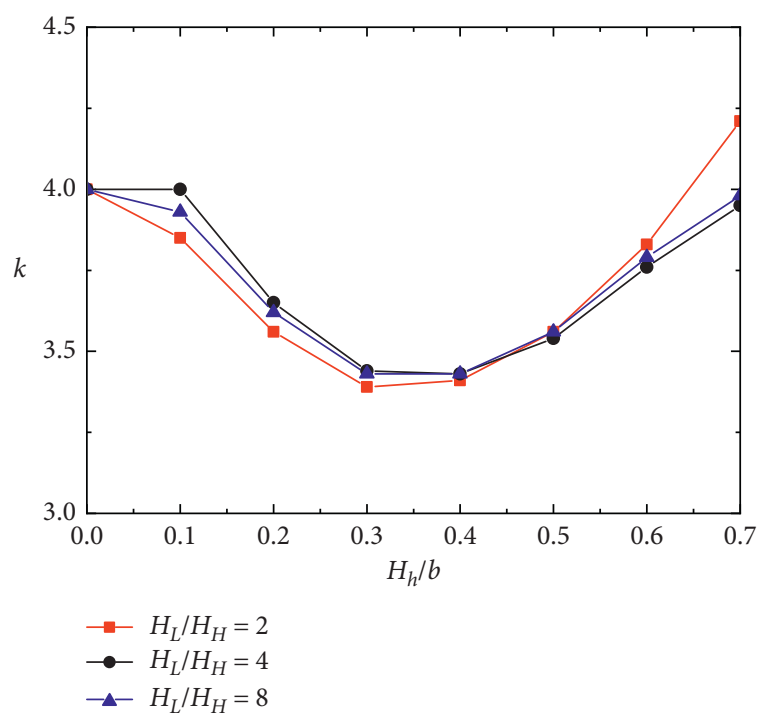

FIGURE 21: Buckling coefficient of plates with rectangular holes. critical dimension of the changing of buckling modes is also equal to 0.36 as shown in Figure 20 . When the ratio of the height of holes to the width of plates $\left(H_{h} / b\right)$ is less than 0.36 , the buckling coefficient of plates with rectangular holes under axial compression can be predicted using formula (5) which is analyzed according to the left part of the curve.

$$
k=4\left[5.91\left(\frac{H_{h}}{b}\right)^{2}-0.017\left(\frac{L_{h}}{H_{h}}\right)^{2}\left(\frac{H_{h}}{b}\right)-0.89\left(\frac{H_{h}}{b}\right)+1\right] .
$$

The local buckling coefficients of the plate strips adjacent to rectangular holes under axial compression can also be determined using formula (3) when the ratio of the height of holes to the width of plates $\left(H_{H} / b\right)$ is more than 0.36 , in which $d$ should be replaced with $L_{h}, b_{1}=\left(b-H_{\mathrm{h}}\right) / 2$.

5.3. Comparison of Ultimate Strengths. The comparison of ultimate strengths determined by using effective width method design formulas (1)-(5) with tests is shown in Table 4 . The mean value and the corresponding coefficient of the variation of the ratio of predicted results and test $\left(P_{M} / P_{t}\right)$ are 0.9571 and 0.0194 . The ultimate strengths predicted by using the proposed effective width method were also compared with the ultimate capacities obtained from FEA for normal sections C7020-02 and C16020-05 as shown in Table 5. The mean value and the corresponding coefficient of variation of the ratio of predicted results and test $\left(P_{M} / P_{A}\right)$ are 0.9548 and 0.0198 . The stud column test in $[2,4,15-17]$ is calculated, and comparison results are shown in Table 6 . The mean value of the prediction-to-test ratio $\left(P_{M} / P_{t}\right)$ is 0.9603 with the corresponding coefficient of variation being 0.0116 . These comparisons show that the calculated ultimate capacities of CFS lipped channel stud columns with holes by using the modified effective width method are safe and accurate, which indicates that the modified effective width method is available for predicting the ultimate strength of the CFS lipped channel stud 
TABLE 6: Comparison of ultimate strengths between tests in [2], [4], and [15] and calculated results using the proposed EWM.

\begin{tabular}{|c|c|c|c|c|}
\hline Reference & Specimen & $P_{t}(\mathrm{kN})$ & $P_{M}(\mathrm{kN})$ & $P_{M} / P_{t}$ \\
\hline \multirow{36}{*}{ [2] } & A-2-1 & 86.18 & 84.46 & 0.98 \\
\hline & A-2-2 & 86.34 & 82.88 & 0.96 \\
\hline & A-2-3 & 86.79 & 84.19 & 0.97 \\
\hline & A-4-1 & 82.10 & 78.00 & 0.95 \\
\hline & A-4-2 & 82.56 & 79.25 & 0.96 \\
\hline & $A-4-3$ & 82.40 & 78.28 & 0.95 \\
\hline & A-6-1 & 78.98 & 77.40 & 0.98 \\
\hline & A-6-2 & 77.97 & 76.41 & 0.98 \\
\hline & A-6-3 & 79.33 & 76.95 & 0.97 \\
\hline & B-2-1 & 84.87 & 79.78 & 0.94 \\
\hline & B-2-2 & 85.08 & 80.82 & 0.95 \\
\hline & B-2-3 & 86.18 & 81.87 & 0.95 \\
\hline & B-4-1 & 82.00 & 79.54 & 0.97 \\
\hline & B-4-2 & 82.05 & 78.77 & 0.96 \\
\hline & B- $4-3$ & 82.56 & 80.90 & 0.98 \\
\hline & B-6-1 & 76.96 & 72.34 & 0.94 \\
\hline & B-6-2 & 78.42 & 74.50 & 0.95 \\
\hline & B-6-3 & 79.13 & 74.38 & 0.94 \\
\hline & A1-2-1 & 54.04 & 53.12 & 0.98 \\
\hline & A1-2-2 & 54.04 & 52.33 & 0.97 \\
\hline & A1-2-3 & 53.89 & 52.21 & 0.97 \\
\hline & A1-4-1 & 54.04 & 52.28 & 0.97 \\
\hline & A1-4-2 & 53.04 & 51.18 & 0.96 \\
\hline & A1-4-3 & 53.14 & 51.97 & 0.98 \\
\hline & A1-6-1 & 48.34 & 46.91 & 0.97 \\
\hline & A1-6-2 & 45.74 & 43.66 & 0.95 \\
\hline & A1-6-3 & 47.34 & 47.06 & 0.99 \\
\hline & B1-2-1 & 53.17 & 51.58 & 0.97 \\
\hline & B1-2-2 & 53.12 & 50.47 & 0.95 \\
\hline & B1-2-3 & 54.63 & 52.45 & 0.96 \\
\hline & B1-4-1 & 52.42 & 51.37 & 0.98 \\
\hline & B1-4-2 & 51.71 & 50.16 & 0.97 \\
\hline & B1-4-3 & 50.00 & 47.50 & 0.95 \\
\hline & B1-6-1 & 48.08 & 45.20 & 0.94 \\
\hline & B1-6-2 & 47.07 & 44.72 & 0.95 \\
\hline & B1-6-3 & 46.97 & 45.09 & 0.96 \\
\hline \multirow{6}{*}[4]{} & $362-1-24-\mathrm{H}$ & 44.5 & 41.83 & 0.94 \\
\hline & $362-2-24-\mathrm{H}$ & 46.2 & 43.89 & 0.95 \\
\hline & $362-3-24-\mathrm{H}$ & 44.2 & 42.87 & 0.97 \\
\hline & $600-1-24-\mathrm{H}$ & 54.0 & 52.92 & 0.98 \\
\hline & $600-2-24-\mathrm{H}$ & 51.7 & 50.15 & 0.97 \\
\hline & $600-3-24-\mathrm{H}$ & 52.4 & 51.35 & 0.98 \\
\hline \multirow{15}{*}{ [15] } & $75-1.5-1$ & 70.00 & 67.2 & 0.96 \\
\hline & $75-1.5-2$ & 75.00 & 71.25 & 0.95 \\
\hline & $75-1.5-3$ & 74.00 & 72.52 & 0.98 \\
\hline & $114-1.5-1$ & 75.00 & 72.75 & 0.97 \\
\hline & $114-1.5-2$ & 76.00 & 72.96 & 0.96 \\
\hline & $114-1.5-3$ & 73.00 & 69.35 & 0.95 \\
\hline & $130-1.5-1$ & 73.00 & 70.81 & 0.97 \\
\hline & $130-1.5-2$ & 76.00 & 72.2 & 0.95 \\
\hline & $130-1.5-3$ & 78.00 & 76.44 & 0.98 \\
\hline & $114-1.2-1$ & 42.00 & 40.32 & 0.96 \\
\hline & $114-1.2-2$ & 40.00 & 38.4 & 0.96 \\
\hline & $114-1.2-3$ & 40.00 & 39.2 & 0.98 \\
\hline & $130-1.2-1$ & 43.00 & 41.28 & 0.96 \\
\hline & $130-1.2-2$ & 43.00 & 41.71 & 0.97 \\
\hline & $130-1.2-3$ & 43.00 & 41.71 & 0.97 \\
\hline \multirow{2}{*}{ [16] } & S240-t1.75-L420-UH & 81.2 & 80.02 & 0.98 \\
\hline & S240-t2.10-L420-UH & 100.5 & 96.74 & 0.96 \\
\hline
\end{tabular}

TABle 6: Continued.

\begin{tabular}{ccccc}
\hline Reference & Specimen & $P_{t}(\mathrm{kN})$ & $P_{M}(\mathrm{kN})$ & $P_{M} / P_{t}$ \\
\hline$[17]$ & $\mathrm{C} 190 \times 45 \times 15-\mathrm{L} 750-\mathrm{UH} 1$ & 60.6 & 57.22 & 0.94 \\
\hline Average & & 0.9603 \\
& Standard deviation & & 0.0111 \\
& Coefficient of variation & & 0.0116 \\
\hline
\end{tabular}

columns with holes. Meanwhile, we need to note that the proposed method in this paper cannot predict the ultimate strength of the CFS channels with edge-stiffened holes as listed in [16-18].

\section{Conclusion}

The lipped channel section with holes is the common member used in CFS building. A total of 28 CFS stud columns subjected to axial compression were tested in this paper. Based on the test investigation, finite element analysis, and effective width method, some conclusions can be obtained as follows.

The ultimate capacity of stud columns decreased with the increase of the dimension of holes. Small holes had a slight effect on the ultimate strength of stud columns with holes, whereas the large hole had a great effect on the ultimate strength of the stud column with holes. The local buckling and the interaction of local buckling and distortional buckling were observed in the test. The presence of holes could lead to the change of buckling modes because the hole in the web decreases the torsional constraint of the web to the flange. The buckling deformation increased with the increase of the dimension of holes.

Finite element simulation for buckling modes and ultimate load capacities of CFS lipped channel stud columns with holes was reliable and accurate. The finite element parametric analysis indicated that the dimensions of holes had a great effect on the ultimate strength of CFS lipped channel stud columns with holes.

The effective width method was used to predict the ultimate strengths of stud columns with holes based on the new design formulas of the buckling coefficient of the plate with holes. The comparisons between calculated results and test results, finite element results, and test results conducted by other researchers indicated that the proposed EWM was feasible and accurate to predict the ultimate strength of the CFS lipped channel stud columns with holes.

The ratio of the diameter of circular holes to the width of the web $(d / h)$ should be less than 0.7 , and the ratio of the height of rectangular holes to the width of the web $\left(H_{h} / h\right)$ should be less than 0.6 in order to avoid the large decrease of load-carrying capacities of CFS lipped channel stud columns with holes because of the effect of holes in cold-formed steel structure.

\section{Data Availability}

The data used to support the findings of this study are available from the corresponding author upon request. 


\section{Conflicts of Interest}

The authors declare that there are no conflicts of interest regarding the publication of this paper.

\section{Acknowledgments}

The authors are grateful for the financial support provided by the Natural Science Foundation Projects of Jiangxi Province in China (no. 20181BAB206040), National Natural Science Foundation Projects of China (no. 51868049), and Department of Education Science and Technology Projects of Jiangxi Province in China (nos. GJJ170983 and GJJ180932).

\section{References}

[1] R. A. O. Colberg, "The load carrying capacity of perforated cold-formed steel columns," Thesis, Cornell University, New York, NY, USA, 1981.

[2] K. S. Sivakumaran, "Load capacity of uniformly compressed cold-formed steel section with punched web," Canadian Journal of Civil Engineering, vol. 14, no. 4, pp. 550-558, 1987.

[3] N. A. Rahman, Cold-Formed Steel Compression Members with Perforations, McMaster University, Hamilton, Canada, 1997.

[4] C. D. Moen and B. W. Schafer, "Experiments on cold-formed steel columns with holes," Thin-Walled Structures, vol. 46, no. 10, pp. 1164-1182, 2008.

[5] L. Xu, Y. Shi, and S. Yang, "Compressive strength of coldformed steel c-shape columns with slotted holes," in Proceedings of Twenty-second International Specialty Conference on Cold-Formed Steel Structures: Recent Research and Developments in Cold-Formed Steel Design and Construction, pp. 157-170, University of Missouri-Rolla, Saint Louis, MI, USA, November 2014.

[6] B. He and G. Zhao, "Analysis on buckling behavior of coldformed lipped channel with perforated web," Journal of Xi'an Institute Metallica \& Construction Engineering, vol. 21, no. 1, pp. 1-9, 1989, in Chinese.

[7] M. L. Dung, P. T. Chung, J. L. Liu, and C. L. Pan, "The compressive strength of slender C-shaped cold-formed steel members with web openings," International Journal of Steel Structure, vol. 9, no. 3, pp. 231-240, 2009.

[8] Y. Yao, Z. Wu, B. Cheng et al., "Experimental investigation into axial compressive behavior of cold-formed thin-walled steel columns with lipped channel and openings," Journal of South China University of Technology, vol. 39, no. 9, pp. 61-67, 2011, in Chinese.

[9] C. D. Moen and B. W. Schafer, "Elastic buckling of coldformed steel columns and beams with holes," Engineering Structures, vol. 31, no. 12, pp. 2812-2824, 2009.

[10] X. Yao, Y. Guo, Y. Liu et al., "Analysis on distortional buckling of cold-formed thin-walled steel lipped channel steel members with web openings under axial compression," Industrial Construction, vol. 50, no. 1, pp. 170-177, 2020, in Chinese.

[11] C. D. Moen and B. W. Schafer, "Direct strength method for design of cold-formed steel columns with holes," Journal of Structural Engineering, ASCE, vol. 137, no. 5, pp. 559-570, 2016.

[12] AISI S100-16, North American Specification for the Design of Cold-Formed Steel Structural Members, American Iron and Steel Institute, Washington, DC, USA, 2016.
[13] GB50018-2002, Technical Code for Cold-Formed Thin-Walled Steel Structures, Chinese National Standard, Beijing, China, 2002, in Chinese.

[14] GB/T 228.1-2010, Test Method for Tensile Test Room Temperature of Metallic Materials, Chinese National Standard, Beijing, China, 2011, in Chinese.

[15] ABAQUS, ABAQUS/Standard User's Manual Volumes I-III and ABAQUS CAE Manual, Dassault Systemes Simulia Corporation, Johnston, RI, USA, 2014.

[16] B. Chen, K. Roy, A. Uzzaman, G. Raftery, and J. B. P. Lim, "Axial strength of back-to-back cold-formed steel channels with edge-stiffened holes, un-stiffened holes and plain webs," Journal of Constructional Steel Research, vol. 174, Article ID 106313, 2020.

[17] B. Chen, K. Roy, A. Uzzaman et al., "Effects of edge-stiffened web openings on the behaviour of cold-formed steel channel sections under compression," Thin-Walled Structures, vol. 144, Article ID 106307, 2019.

[18] B. Chen, K. Roy, A. Uzzaman, G. M. Raftery, and J. B. P. Lim, "Parametric study and simplified design equations for coldformed steel channels with edge-stiffened holes under axial compression," Journal of Constructional Steel Research, vol. 172, Article ID 106161, 2020. 